\title{
ОЦЕНКА И МОНИТОРИНГ БЛАГОПОЛУЧИЯ СТАРШЕГО ПОКОЛЕНИЯ В ТОМСКОЙ ОБЛАСТИ (ПО МАТЕРИАЛАМ РОССИЙСКОГО ИНДЕКСА БЛАГОПОЛУЧИЯ СТАРШЕГО ПОКОЛЕНИЯ)
}

\author{
Павлова Ирина Анатольевна1,2,3, \\ iapav@mail.ru \\ Недоспасова Ольга Павловна², \\ olgaeconomy@mail.ru \\ Гуменников Илья Владимирович1, \\ gumennikov@tpu.ru \\ ${ }^{1}$ Национальный исследовательский Томский политехнический университет, \\ Россия, 634050, г. Томск, пр. Ленина, 30 \\ 2 Национальный исследовательский Томский государственный университет, \\ Россия, 634050, г. Томск, пр. Ленина, 36 \\ 3 Томский государственный университет систем управления и радиоэлектроники, \\ Россия, 634050, г. Томск, пр. Ленина, 40
}

\begin{abstract}
Павлова Ирина Анатольевна, кандидат экономических наук, доцент Школы инженерного предпринимательства Национального исследовательского Томского политехнического университета; доцент Института экономики и менеджмента Национального исследовательского Томского государственного университета; доцент кафедры управления инновациями Томского государственного университета систем управления и радиоэлектроники.
\end{abstract}

Недоспасова Ольга Павловна, доктор экономических наук, профессор Института экономики и менеджмента Национального исследовательского Томского государственного университета.

Гуменников Илья Владимирович, программист Национального исследовательского Томского политехнического университета.

Актуальность. Глобальное демографическое старение актуализировало необходимость поиска эффективных решений по широкому спектру проблем, связанных с благополучием граждан старшего возраста: от финансово-экономических до эмоционально-психологических. Фокусирование общественного внимания на проблемах пожилых людей повлекло за собой требование институциональных изменений, принятия важных общественно-политических решений для повышения качества жизни граждан старшего возраста как самой быстрорастущей социальной группы, совершенствования традиционных и появления новых инструментов оценки и мониторинга прогресса в данной сфере как на индивидуальном уровне, так и на уровне регионов, стран, международных организаций. Кроме хорошо известных в международной практике индексов (Active Ageing Index и Global AgeWatch) в российском исследовательском арсенале есть Российский индекс благополучия старшего поколения (РИБСП), разработанный исследователями Международной научно-образовательной лаборатории технологий улучшения благополучия пожилых людей при Томском политехническом университете. РИБСП объективно не свободен от недостатков, свойственных методу в целом, однако с его помощью можно отслеживать динамику изменений в качестве жизни старшего поколения для России в целом и ее отдельных регионов, сравнивать их рейтинговые позиции в пределах одного или нескольких периодов, выдвигать гипотезы о причинах изменений, анализировать их, формулировать предложения о мерах, способных улучшить качество жизни пожилых людей в том или ином регионе. Цель исследования: по материалам РИБСП за 2014, 2016 и 2018 г2. проанализировать изменения в оценке благополучия по- 
жилых людей в Томской области и по итогам трех раундов общероссийского исследования формулировать выводы о динамике изменений качества жизни пожилых людей. Методы: статистический анализ по оригинальной методике расчета РИБСП на основе микроданных исследования Росстата «Комплексное наблюдение условий жизни населения» (КОУЖ) за 2014, 2014 и 2018 г2. Результаты: анализ показал ухудшение значений практически по всем доменам РИБСП (экономика, социум, здоровье, инфраструктура и качество жизни в региональном измерении) в целом по РФ за весь период наблюдений; ухудшение рейтинговых позиций Томской области по РИБСП в 2016 и 2018 г2. относительно 2014 г.; заметное снижение балльных значений по большинству доменов и частных индикаторов индекса для Томской области в 2018 г. Выводы: по результатам анализа значений РИБСП за три периода наблюдений формулированы выводы как о возможностях и объективных ограничениях в использовании данного индекса для оценки качества жизни и благополучия старшего поколения в РФ, так и для анализа динамики соответствующих процессов в отдельных регионах. Выдвинуты предположения о возможных причинах негативной динамики Томской области в рейтинге по РИБСП в целом и по его отдельным доменам и индикаторам. На основе полученных данных сделаны предварительные выводы о рисках невыполнения национального плана действий по повышению качества жизни пожилых людей. Сделано предположение о том, что рассматриваемые проблемы смогут привлечь больше внимания при внедрении Российского индекса благополучия старшего поколения, разработанного в соответствии с международной методологией.

Ключевые слова: Пожилые люди, старшее поколение, благополучие, качество жизни, интегральные индексы, Россия, Томская область.

\section{Введение}

Российское общество в рамках амбициозной национальной цели «Сохранение населения, здоровье и благополучие людей» [1] планирует к 2030 г. занять весьма достойное место в группе стран с ожидаемой продолжительностью жизни при рождении на уровне 78 лет. Для достижения данной цели требуется решение множества социальноэкономических проблем (как относительно новых, так и «застарелых»), приведение многих весьма архаичных для реалий XXI в. российских институтов в соответствие с ускоряющимися демографическими сдвигами и вызовами «экономики старения» [2]. Не менее важны наличие корректных и актуальных статистических данных, научное обоснование и корректное использование современных аналитических инструментов, способных помочь политикам и чиновникам более четко видеть динамику текущих процессов, понимать их причины, оперативно предлагать и осуществлять рациональные решения, направленные на рост благополучия и повышение качества жизни пожилых людей.

В последние годы международные организации, группы ученых из разных стран и их коллаборации уделяют особое внимание разработке специальных индексов, а также формированию на их основе рейтингов, характеризующих мировой прогресс и динамику отдельных стран и регионов в вопросах качества жизни старшего поколения. Наиболее известными и востребованными среди них по праву стали международные индексы Active Ageing Index и Global AgeWatch. Однако значительная научно-исследовательская работа в этом направлении проводится и в регионах РФ. Так, например, весомым потенциалом в деле мониторинга региональной ситуации, поиска и обоснования решений о повышении качества жизни пожилых людей обладает Российский индекс благополучия старшего поколения (РИБСП), разработанный учеными Международной научно-образовательной лаборатории технологий улучшения благополучия пожилых людей при Томском политехническом университете. Целью данной работы является знакомство читателей с результатами мониторинга и сравнительного анализа благополучия пожилых людей в Томской области, полученными по материалам РИБСП за 2014, 2016 и 2018 гг.; 
формулирование выводов по итогам трех раундов исследования; их обсуждение в контексте выполнения национального плана действий по повышению качества жизни пожилых людей и его согласованности с международными трендами в данной сфере.

\section{Международные интегральные индексы оценки благополучия пожилых людей}

Начиная с 2010-х гг. активное развитие получили два международных индекса для оценки качества жизни и благополучия старшего поколения - Индекс активного долголетия (Active Ageing Index, AAI) и Global AgeWatch. Эти грантовые исследовательскиприкладные проекты к настоящему времени можно признать успешно реализованными. Так, AАI заявлялся как региональный инструмент для количественного оценивания возможностей и способностей реализации ресурсного потенциала старшего поколения по ряду направлений социально-экономического развития, включая участие пожилых людей на рынке труда и в социальной жизни общества в странах Европейского союза. Структура данного индекса призвана показать, что ресурсный потенциал старшего поколения может быть важнейшим активом для социального прогресса при условии увеличения продолжительности и улучшения качества жизни пожилых людей [3]. Важно, что AAI ориентирован на оценку и раскрытие нереализованного вклада - незадействованного потенциала (англ. - untapped potential) старшего поколения для участия в социально-экономической жизни общества при условии независимой и самодостаточной жизни. AAI включает в себя 22 индикатора в четырех доменах: 1) занятость; 2) участие в социальной жизни; 3) независимое, здоровое и безопасное проживание; 4) возможности и благоприятная среда для активного долголетия. В настоящее время проект охватывает не только ЕС, но и другие страны и регионы, что потребовало адаптации основной методики к локальным условиям. Еще одним важным результатом проекта стало привлечение к исследованиям органов статистики разных стран, что позволило унифицировать национальные подходы к мониторингу и оценке активного долголетия и синхронизировать сбор данных в европейских регионах. Это стало важным прорывом в понимании текущего состояния и потенциальных возможностей вовлечения старшего поколения в социально-экономическое развитие. Накопленный опыт, фиксируемый в AAI, важен и для стран, не входящих в ЕС. Даже принимая в расчет культурно-исторические, институциональные особенности, национальную специфику организации статистической работы, не позволяющих делать в полной мере корректные сравнения со странами Евросоюза, AAI может быть важным инструментом мониторинга положительных или отрицательных изменений в уровне благополучия, качестве жизни и степени реализации ресурсного потенциала старшего поколения практически для любой страны мира. Как отмечается в отчете ООН по данному индексу за 2018 г., благодаря измерениям, предусмотренным в AАI, вклад пожилых людей в жизнь общества становится более заметным, при этом динамика индекса и его индикаторов помогает политикам и другим заинтересованным сторонам понять, в каких сферах общественной и частной жизни возникают наиболее сложные ситуации и где требуются самые активные действия для балансирования интересов стареющего общества [4].

Второй индекс - Global AgeWatch - изначально заявлялся как международный проект и за 2013-2015 гг. его значения были единообразно рассчитаны для 96 стран по 13 индикаторам четырех доменов социально-экономического благополучия старшего поколения: 1) экономическая безопасность (пенсионный охват, уровень бедности в старшем возрасте, относительное благосостояние старшего поколения, ВНД на душу населения); 2) благоприятная среда (социальные связи, физическая безопасность, гражданские свободы, доступ к общественному транспорту); 3 ) состояние здоровья (продолжительность 
жизни в возрасте 60 лет, ожидаемое количество здоровых лет жизни для людей в возрасте 60 лет, психологическое благополучие); 4) возможности (занятость в старшем возрасте, образовательный статус лиц старшего возраста). Данный индекс был в значительной степени ориентирован на оценку именно экономической и финансовой безопасности граждан старшего возраста, в том числе их охват пенсионным доходом, поэтому низкий уровень пенсионного обеспечения в той или иной стране или его отсутствие неизбежно ухудшали ее позиции в глобальном рейтинге. Существенной проблемой при расчетах Global AgeWatch стал недостаток и (или) большое количество пропущенных данных по ряду стран и периодов. После 2015 г. индекс не рассчитывался, поскольку его разработчики заявили о необходимости доработки методологии. Тем не менее проект продолжается и с 2018 г. GlobalAgeWatch публикует материалы сравнительного анализа по ряду индикаторов, которые не только отражают важные аспекты благополучия, качества жизни и реализации ресурсного потенциала старшего поколения, но и акцентируют внимание общественности на проблемах, с которыми сталкиваются пожилые люди, в частности показывают, что следует предпринять в странах с низким и средним уровнем экономического развития, для того чтобы адаптироваться к глобальным демографическим и эпидемиологическим изменениям [5].

Менее известны, но, безусловно, представляют исследовательский интерес и другие многомерные международные индексы, применяемые в данной сфере: Глобальный пенсионный индекс (Natixis Global Retirement Index), Индекс благополучия пожилых (Wellbeing in Later Life Index, WILL), Индекс благосостояния пожилых людей (SCL/PRB). Обобщая опыт применения рассмотренных выше интегральных индексов AAI и Global AgeWatch, отметим, что общей проблемой индексной оценки качества жизни и благополучия старшего поколения является сложность отслеживания прогресса по конкретной стране: ежегодная рейтинговая таблица (по определению) предполагает сравнительную оценку стран, их ранжирование относительно друг друга. Следовательно, изменение позиции какоголибо государства в рейтинге демонстрирует в первую очередь не столько только его национальный прогресс, сколько прогресс стран относительно друг друга, что затрудняет отслеживание реального прогресса в какой-либо отдельной взятой стране (именно по результатам расчета индекса) и выделение отдельных факторов успеха или неудач.

\section{Российский индекс благополучия старшего поколения}

По ряду причин Российская Федерация не входит в большинство глобальных индексов. Это может быть связано с целями разработки самих индексов (например, индекс разрабатывается для конкретной страны, макрорегиона, определенного пула стран) и с недостатком данных (по конкретным показателям данные в России не собираются, что слишком усложняет процесс расчета индекса или делает физически невозможным включение в индекс конкретной страны). Однако активная позиция России при реализации Мадридского международного плана действий по проблемам старения [6] способствовала принятию ряда крайне значимых для повышения уровня благополучия пожилых людей документов: национальной «Стратегия действий в интересах граждан старшего поколения в Российской Федерации до 2025 года» [7], национального проекта «Демография» [8] и федерального проекта «Старшее поколение» [9], в том числе ускорило переход к применению в нашей стране международных метрик для оценки благополучия пожилых людей и, в частности, расчета Российского индекса активного долголетия (РИАД) [10]. Для этого Росстат в 2019 г. специальный приказом утвердил методику его расчета [11]. Методологически РИАД призван практически повторить методологию Индекса активного долголетия (Active Ageing Index, AAI), однако на практике, вполне вероятно, он 
будет претерпевать методологические изменения, которые будут связаны с российскими возможностями статистического мониторинга и сбора данных.

Принимая в расчет то, что Российский индекс активного долголетия пока только анонсирован, отметим, что для оценки благополучия граждан старшего возраста в Российской Федерации коллективом МНОЛ ТУБПЛ НИ ТПУ разработан и применяется Российский индекс благополучия старшего поколения (РИБСП) [12]. Структура РИБСП в целом соответствует логике формирования глобальных индексов для оценки благополучия старшего поколения, принятой для Active Ageing Index и GlobalAgeWatch: в нем четыре основных домена, характеризующих экономику, социум, здоровье и региональное пространство с точки зрения их влияния на качество жизни пожилых людей и отражения в них тех или иных аспектов благополучия граждан старшего возраста, в том числе включение в индекс субъективных оценок благополучия.

Важно отметить, что к старшему поколению при расчете РИБСП отнесены женщины в возрасте 55+ и мужчины в возрасте 60+. Такие возрастные границы были выбраны для ретроспективного анализа как в связи с наличием в РФ переходного периода для увеличения пенсионного возраста, так и потому, что в актуальных формах Росстата ряд объективных показателей для анализа представлен в разрезе именно таких возрастных категорий. Источниками данных для РИБСП являются открытые формы Росстата, а также данные «Комплексного обследования условий жизни населения» (КОУЖ).

В течение текущего года авторы провели уточненный расчет РИБСП для всех российских регионов на основе данных КОУЖ-2018, а также сравнили его результаты с аналогичными значениями за 2014 и 2016 гг. (рис. 1).

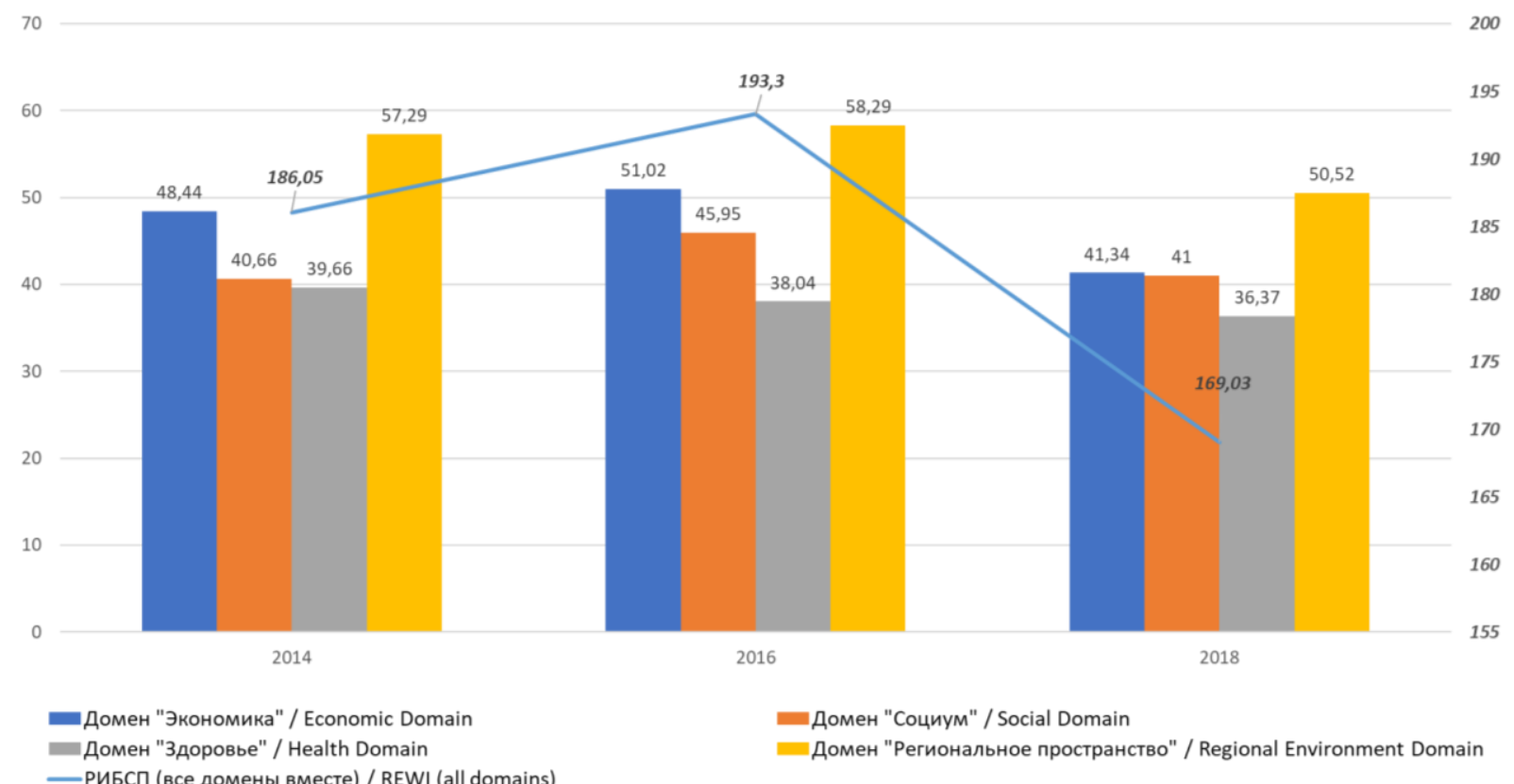

Puc. 1. Динамика изменения РИБСП за 2014, 2016 и 201822.

Fig. 1. REWI dynamic for 2014, 2016, 2018

Анализ показал, что за 2014-2018 гг. наблюдается неустойчивая и в целом негативная динамика РИБСП по его отдельным доменам и по итоговым значениям индекса. По трем доменам (экономика, социум и региональное пространство) наилучшие значения 
были достигнуты в 2016 г., при этом также по трем доменам, но в несколько другой комбинации (экономика, здоровье, и региональное пространство) наихудшие значения оказались для 2018 г. Такие выводы дополнительно актуализируют все аспекты благополучия пожилых людей, магистрально обозначенные в национальной «Стратегии действий в интересах граждан старшего поколения» и усиливают важность их масштабного финансового наполнения как важнейшего условия выполнения каждого целевого показатели ее реализации: например, увеличения доли граждан старшего поколения, занимающихся физической культурой и спортом в 2025 г. до $10 \%$ против $6 \%$ в 2020 г.; роста обеспеченности геронтологическими койками в количестве 5 на 10000 для населения в возрасте 60 лет и старше (по сравнению с аналогичным показателем для 2020 г. на уровне $2,26)$; увеличения доли граждан старшего поколения, получивших социальное обслуживание от общего числа граждан старшего поколения, признанных нуждающимися в социальном обслуживании за тот же период, с 80 до 100 \% и т. п. [13].

Менее важны и институциональные изменения в каждой из сфер - системные преобразования, связанные с экономической, социальной, медицинской и психологической защитой и безопасностью пожилых людей для воплощения в жизнь идей активного долголетия.

Наилучшие значения РИБСП в каждом периоде были характерны для домена «Региональное пространство», но в 2018 г. этот показатель довольно существенно снизился. Особо хочется отметить, что значения в домене «Здоровье» за весь период наблюдений оказывались не только ниже, чем по другим доменам, но и последовательно снижались. Этот вывод совпадает с авторитетным экспертным мнением о весьма низком (в сравнении со странами, имеющими сравнимый с РФ уровень экономического развития) капитале здоровья российских граждан старшего возраста [14]. В 2018 г. ни один из доменов не показал роста относительно 2016 г. Все это привело к тому, что общее значение РИБСП (после его роста в 2016 г.) в 2018 году оказалось даже ниже, чем в 2014-м. Полученные результаты позволяют согласиться с экспертным мнением о том, что фиксируемое в период наблюдений увеличение средней продолжительности жизни в России пока не привело к повсеместному распространению устойчивых практик активного долголетия [15]. Они, к сожалению, существуют в основном как относительно успешные региональные кейсы, широкое масштабирование которых затруднено или невозможно по ряду институциональных или социально-экономических причин [16]. При этом нельзя недооценивать вклад в повышение благополучия и качества жизни со стороны некоммерческих организаций и волонтёров. Например, программа благотворительного фонда Елены и Геннадия Тимченко «Старшее поколение» уже 10 лет сфокусирована на объединении самых разных людей и организаций для помощи пожилым людям именно на местном уровне [17].

В ходе первого года реализации проекта (при сравнении результатов РИБСП за 2014 и 2016 гг.) было сделано предположение о том, что основной причиной различной динамики значений в каждом домене является особенность формирования структуры индекса и соотношения в ней объективных и субъективных индикаторов. Было установлено, что в 2016 г. наиболее явным было ухудшение значений индекса в тех доменах, где наибольшую долю составляли субъективные индикаторы (самооценка здоровья, субъективное отношение к обеспеченности услугами, оценка качества жизни и физической инфраструктуры и т. д.) - «Здоровье» и «Региональное пространство». Именно субъективные оценки транслируют удовлетворенность (или неудовлетворённость) человека разными аспектами его жизни в итоговые значения индекса. В 2016 г. это проявилось особенно явно в домене «Региональное пространство», где негативная динамика именно субъективных оценок 
была наиболее заметна. Там, где респонденты оценивали качество среды и разные аспекты обеспеченности сервисами в конкретной географической локации, очень явно проявляется персонифицированная оценка пожилыми гражданами качества своей жизни и качества работы региональных органов власти. Такой вывод был сделан на основе того, что субъективные оценки априори более чувствительны к изменениям в отличие от показателей макроуровня, связанных, например, с уровнем зарплат или образования. Не исключено, что негативные субъективные оценки респондентов по различным аспектам благополучия пожилых людей потенциального могут стать причиной ухудшения соответствующих позиций губернаторов в их неофициальном рейтинге. Так, например, руководитель Томской области в настоящее время занимает лишь 60-е место, набрав при оценке уровня жизни населения в регионе менее трех баллов [18].

Другое предположение, также сделанное в ходе первого раунда проекта, нацеленного преимущественно на сравнение значений для 2014 и 2016 гг. (о том, что объективные показатели, несмотря на то, что они менее чувствительны к изменениям макроуровня, тем не менее подчиняются тому же тренду, что и субъективные оценки), при финализации расчетов РИБСП за 2018 г. также нашло свое подтверждение. По результатам 2018 г. ухудшение наблюдается даже по самому перспективному направлению оценивания - «Экономика», - в котором в 2016 г. был достигнут незначительный, но все же рост. В данном случае выводы сделаны на основе изменений итогового расчетного значения по отдельным доменам и по индексу в целом.

Критика индексного метода, как уже отмечалось, обычно связана с особенностями его методологии. С учетом процедуры нормирования выбирается диапазон для нормализации, которым в РИБСП является «минимум-максимум». Следовательно, важен вопрос о специфике итоговых оценок индекса и их сопоставимости. Очевидно, что результаты индекса могут трактоваться двумя путями: 1) по значению итогового расчетного балла (в РИБСП влияние относительности оценки минимально); 2) позиции региона в рейтинговой таблице (которая является всего лишь относительной оценкой). Изменения в рейтинговой таблице (как улучшение, так и ухудшение рейтинга конкретного региона) могут быть связаны с его собственной динамикой и с интенсивностью позитивных и (или) негативных изменений в других регионах. Иными словами, не исключено, что в каком-либо регионе в отчетном году могут быть зафиксированы те же самые показатели, что и в прошлом, но в рейтинговой таблице он, возможно, сдвинется вниз относительно других регионов, если в других регионах РФ будет достигнута более существенная положительная динамика изменений, которые отразятся в соответствующих индикаторах индекса.

\section{Томская область в рейтинге РИБСП}

Позиции Томской области в рейтинге РИБПС за анализируемый период последовательно ухудшаются. Если в 2014 г. она занимала 35-е место, то в 2014-м - уже 75-е, а в 2018 г. сместилась на 81-е место. Томская область имеет значения, превышающие средние для РФ, только по очень ограниченному количеству нормализованных и агрегированных индикаторов РИБСП. Для Томской области характерны в основном либо средние для России показатели, либо хуже среднероссийских, исключением здесь являются домены «Экономика» и «Социум» за 2014 г., где значения для Томской области оказались ваше среднероссийских (рис. 2). 


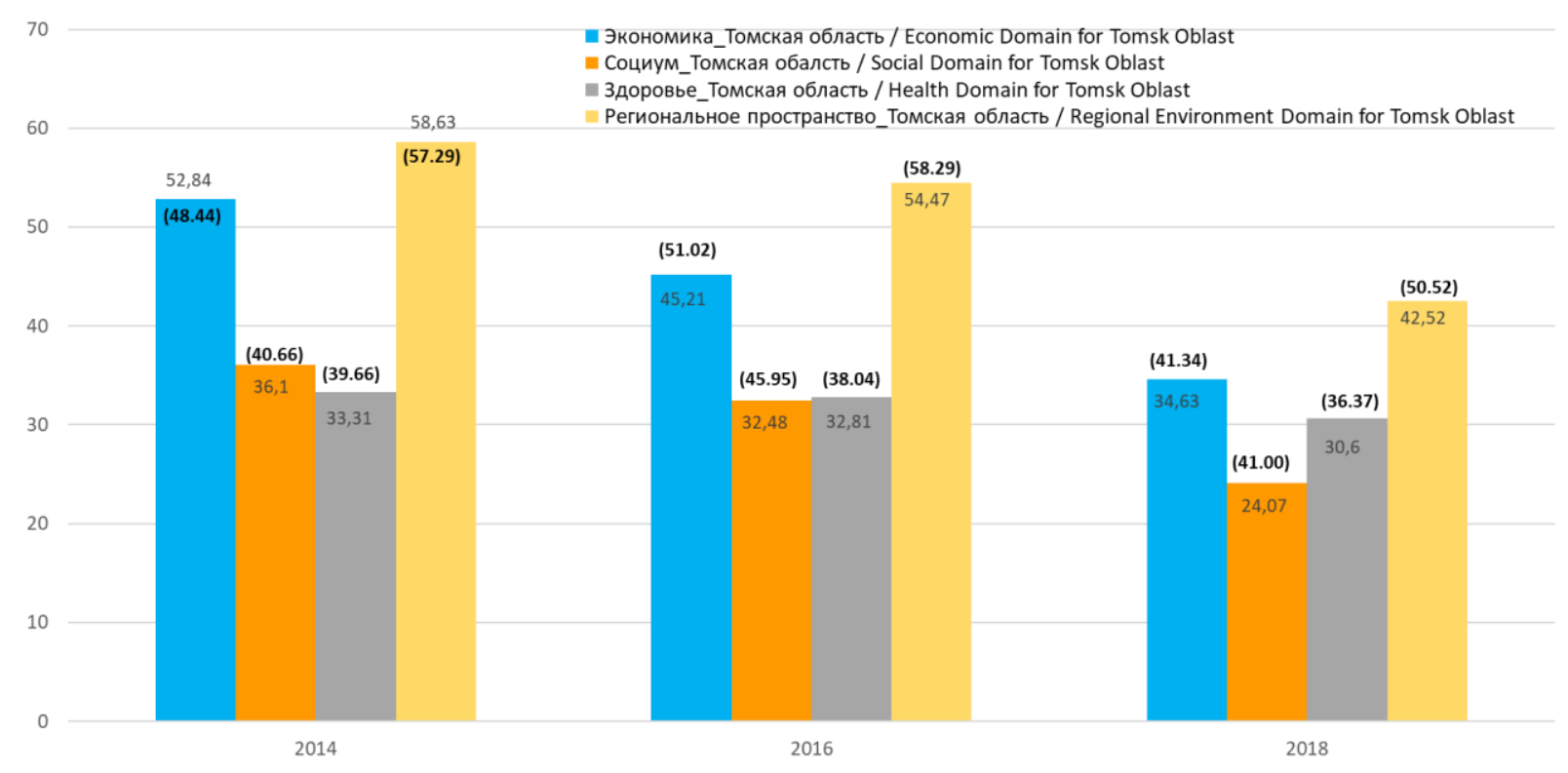

Соответствующие данные для РФ в целом представлены в скобках / Values for the Russian Federation are given in brackets

Puc. 2. Томская область через призму доменов РИБСП

Fig. 2. Tomsk Oblast through the prism of the REWI domains

Для того чтобы дать более полную характеристику качества жизни и благополучия пожилых людей в Томской области, рассмотрим региональные значения РИБСП в ракурсе отдельных ненормализованных показателей и сравним их с соответствующими среднероссийскими (табл. 1).

Таблища 1. Сравнение значений по индикаторам РИБСП для Томской области со среднероссийскими значениями в 2014, 2016, 2018 г2.

Table 1. REWI indicators values comparing for Tomsk Oblast and Russian average in 2014, 2016, 2018

\begin{tabular}{|c|c|c|c|c|}
\hline №/\# & $\begin{array}{l}\text { Индикатор } \\
\text { Indicator }\end{array}$ & $\begin{array}{l}\text { Год } \\
\text { Year }\end{array}$ & $\begin{array}{c}\text { Среднее } \\
\text { значение } \\
\text { по РФ } \\
\text { Russian av- } \\
\text { erage }\end{array}$ & $\begin{array}{c}\text { Значение } \\
\text { для Томской } \\
\text { области } \\
\text { Tomsk Oblast } \\
\text { average }\end{array}$ \\
\hline \multirow{3}{*}{$\begin{array}{l}\text { 1.1. ЭКОН } \\
\text { 1.1. ECON }\end{array}$} & \multirow{3}{*}{$\begin{array}{l}\text { Реальный размер назначенных пенсий, \% } \\
\text { Real size of assigned pensions, \% }\end{array}$} & 2014 & 97,5 & 98,1 \\
\hline & & 2016 & 137,3 & 133,6 \\
\hline & & 2018 & 100,8 & 100,1 \\
\hline \multirow{3}{*}{$\begin{array}{l}\text { 1.2. ЭКОН } \\
\text { 1.2. } \mathrm{ECON}\end{array}$} & \multirow{3}{*}{$\begin{array}{l}\text { Соотношение среднего размера назначенных пенсий с } \\
\text { величиной прожиточного минимума, \% } \\
\text { Ratio of the average size of assigned pensions to the subsist- } \\
\text { ence level, \% }\end{array}$} & 2014 & 160,5 & 170,3 \\
\hline & & 2016 & 217,8 & 226,1 \\
\hline & & 2018 & 166,6 & 180,4 \\
\hline \multirow{3}{*}{$\begin{array}{l}\text { 1.3. ЭКОН } \\
\text { 1.3. } \mathrm{ECON}\end{array}$} & \multirow{3}{*}{$\begin{array}{l}\text { Уровень занятости в возрасте, превышающем трудоспо- } \\
\text { собный, \% } \\
\text { Employment rate over the working age, \% }\end{array}$} & 2014 & 29,5 & 24,8 \\
\hline & & 2016 & 29,8 & 23,9 \\
\hline & & 2018 & 29 & 19,9 \\
\hline \multirow{3}{*}{$\begin{array}{l}\text { 1.4. ЭКОН } \\
\text { 1.4. ECON }\end{array}$} & \multirow{3}{*}{$\begin{array}{l}\text { Наличие на прошлой неделе оплачиваемой работы или } \\
\text { доходного занятия (ж - 55+, м - 60+), \% ответов «Да» } \\
\text { Presence of a paid job or profitable occupation last week } \\
\text { (w } 55+, \text { m } 60+\text { ), \% of «Yes» answers }\end{array}$} & 2014 & 17,95 & 26,45 \\
\hline & & 2016 & 18,17 & 18,21 \\
\hline & & 2018 & 17,16 & 14,74 \\
\hline \multirow{2}{*}{$\begin{array}{l}\text { 1.5. ЭКОН } \\
\text { 1.5. ECON }\end{array}$} & \multirow{2}{*}{$\begin{array}{l}\text { Степень удовлетворенности работой (по } 8 \text { параметрам), } \\
\text { \% ответов «Вполне удовлетворен» }\end{array}$} & 2014 & 73,96 & 72,26 \\
\hline & & 2016 & 73,24 & 68,36 \\
\hline
\end{tabular}




\begin{tabular}{|c|c|c|c|c|}
\hline & $\begin{array}{l}\text { Degree of satisfaction with the job (by } 8 \text { parameters), \% of } \\
\text { responses «Quite satisfied» }\end{array}$ & 2018 & 74,85 & 70,92 \\
\hline \multirow{3}{*}{$\begin{array}{l}\text { 2.1. СOЦ } \\
\text { 2.1. SOC }\end{array}$} & \multirow{3}{*}{$\begin{array}{l}\text { Уровень образования, доля с университетским образова- } \\
\text { нием (бакалавриат, специалитет, магистратура), \% } \\
\text { Educational level, share with university education (bache- } \\
\text { lor's, specialty, master's degree), \% }\end{array}$} & 2014 & 17,47 & 20,65 \\
\hline & & 2016 & 18,48 & $18,93^{*}$ \\
\hline & & 2018 & 18,74 & $13,78^{*}$ \\
\hline \multirow{3}{*}{$\begin{array}{l}\text { 2.2. } \mathrm{CO} \\
\text { 2.2. SOC }\end{array}$} & \multirow{3}{*}{$\begin{array}{l}\text { Помощь детей, проживающих отдельно, \% } \\
\text { Help of children living separately, \% }\end{array}$} & 2014 & 42,68 & 35,75 \\
\hline & & 2016 & 44,65 & 34,51 \\
\hline & & 2018 & 49,6 & 41,7 \\
\hline \multirow{3}{*}{$\begin{array}{l}\text { 2.3. СOЦ } \\
\text { 2.3. SOC }\end{array}$} & \multirow{3}{*}{$\begin{array}{l}\text { Распределение населения, являющегося активными пользо- } \\
\text { вателями сети Интернет, по возрастным группам (доля пен--} \\
\text { сионеров 55-72 лет к общему количеству пользователей), } \\
\% \\
\text { Distribution of the population who are active users of the In- } \\
\text { ternet by age groups (share of retirees 55-72 years old to the } \\
\text { total number of users), \% }\end{array}$} & 2014 & 10,15 & 10,22 \\
\hline & & 2016 & 12,8 & 11,2 \\
\hline & & 2018 & 18,4 & 14,5 \\
\hline \multirow{3}{*}{$\begin{array}{l}\text { 2.4. СOЦ } \\
\text { 2.4. SOC }\end{array}$} & \multirow{3}{*}{$\begin{array}{l}\text { Членство в добровольных организациях (доля ответов), } \\
\% \text { Membership in voluntary organizations (response rate), \% }\end{array}$} & 2014 & 2,41 & 1,3 \\
\hline & & 2016 & 3,6 & 2,1 \\
\hline & & 2018 & 3,37 & 3,85 \\
\hline \multirow{3}{*}{$\begin{array}{l}\text { 2.5. СOЦ } \\
2.5 . \mathrm{SOC}\end{array}$} & \multirow{3}{*}{$\begin{array}{l}\text { Посещение досуговых мероприятий, } 7 \text { параметров } \\
\text { (усредненная доля ответов), \% } \\
\text { Attendance at leisure activities, } 7 \text { parameters (average re- } \\
\text { sponse rate), \% }\end{array}$} & 2014 & 48,59 & 41,29 \\
\hline & & 2016 & 51,49 & 41,79 \\
\hline & & 2018 & 51,66 & 35,9 \\
\hline \multirow{3}{*}{$\begin{array}{l}\text { 3.1. ЗДОР } \\
\text { 3.1. HЕAL }\end{array}$} & \multirow{3}{*}{$\begin{array}{l}\text { Ожидаемая продолжительность предстоящей жизни по } \\
\text { субъектам РФ, лет } \\
\text { Life expectancy in the regions of the Russian Federation, } \\
\text { years }\end{array}$} & 2014 & $\begin{array}{l}15,86(\mathrm{M}) \\
25,52(\%)\end{array}$ & $\begin{array}{l}15,69(\mathrm{M}) \\
25,42(ж)\end{array}$ \\
\hline & & 2016 & $\begin{array}{l}16,08(\mathrm{M}) \\
25,8(\text { (ж) }\end{array}$ & $\begin{array}{l}15,85(\mathrm{M}) \\
25,83(ж)\end{array}$ \\
\hline & & 2018 & $\begin{array}{l}16,56(\mathrm{M}) \\
26,28(ж)\end{array}$ & $\begin{array}{l}16,37(\mathrm{M}) \\
26,16(ж)\end{array}$ \\
\hline \multirow{3}{*}{$\begin{array}{l}\text { 3.2. ЗДОР } \\
\text { 3.2. HЕAL }\end{array}$} & \multirow{3}{*}{$\begin{array}{l}\text { Возможность вести активную жизнь, доля ответов } \\
\text { «Да, могу», \% } \\
\text { The ability to lead an active life, the share of answers } \\
\text { «Yes, I can», \% }\end{array}$} & 2014 & 15,8 & 23,55 \\
\hline & & 2016 & 14,78 & 16,43 \\
\hline & & 2018 & 19,67 & 20,5 \\
\hline \multirow{3}{*}{$\begin{array}{l}\text { 3.3. ЗДОР } \\
\text { 3.3. HЕAL }\end{array}$} & \multirow{3}{*}{$\begin{array}{l}\text { Самооценка состояния здоровья, доля ответов } \\
\text { «Очень хорошо», «Хорошо», «Удовлетворительно», \% } \\
\text { Self-assessment of health status, the share of answers «Very } \\
\text { good», «Good», «Satisfactory», \% }\end{array}$} & 2014 & 72,02 & 73,23 \\
\hline & & 2016 & 74,36 & 72,14 \\
\hline & & 2018 & 74,29 & 69,87 \\
\hline \multirow{3}{*}{$\begin{array}{l}\text { 3.4. ЗДОР } \\
\text { 3.4. HЕAL }\end{array}$} & \multirow{3}{*}{$\begin{array}{l}\text { Отсутствие хронической болезни, установленной вра- } \\
\text { чом, доля ответов «Нет» (заболевание отсутствует), \% } \\
\text { Absence of a chronic disease established by a doctor, } \\
\text { the share of «No» answers (no disease), \% }\end{array}$} & 2014 & 45,02 & 41,61 \\
\hline & & 2016 & 47,05 & 37,5 \\
\hline & & 2018 & 46,23 & 42,62 \\
\hline \multirow{3}{*}{$\begin{array}{l}\text { 3.5. ЗДОР } \\
\text { 3.5. HЕAL }\end{array}$} & \multirow{3}{*}{$\begin{array}{l}\text { Отсутствие вредных привычек (курение), доля ответов } \\
\text { «Нет» (доля некурящих, в т. ч. бросивших курить), \% } \\
\text { Lack of bad habits (smoking), share of «No» answers (share } \\
\text { of nonsmokers, including those who have quitted smoking), } \\
\%\end{array}$} & 2014 & 86,86 & 82,9 \\
\hline & & 2016 & 85,72 & 83,21 \\
\hline & & 2018 & 86,13 & 80,77 \\
\hline \multirow{3}{*}{$\begin{array}{l}\text { 3.6. ЗДОР } \\
\text { 3.6. HЕAL }\end{array}$} & \multirow{3}{*}{$\begin{array}{l}\text { Отсутствие вредных привычек (употребление алкоголя), } \\
\text { доля ответов «Нет», \% } \\
\text { Absence of bad habits (alcohol consumption), share of «No» } \\
\text { answers, \% }\end{array}$} & 2014 & 57,36 & 53,87 \\
\hline & & 2016 & 54,28 & 53,57 \\
\hline & & 2018 & 53,76 & 51,28 \\
\hline \multirow{3}{*}{$\begin{array}{l}\text { 4.1. PEГ } \\
\text { 4.1. REG }\end{array}$} & \multirow{3}{*}{$\begin{array}{l}\text { Оценка домохозяйствами пенсионеров состояния зани- } \\
\text { маемого ими жилого помещения, доля ответов «Отлич- } \\
\text { ное», «Хорошее», «Удовлетворительное», \% } \\
\text { Assessment by households of pensioners of the condition of } \\
\text { the dwelling they occupy, the share of answers «Excellent», } \\
\text { «Good», «Satisfactory», \% }\end{array}$} & 2014 & 94 & 92,7 \\
\hline & & 2016 & 95,1 & 90,7 \\
\hline & & 2018 & 95,1 & 89,1 \\
\hline
\end{tabular}




\begin{tabular}{|c|c|c|c|c|}
\hline \multirow{3}{*}{$\begin{array}{l}\text { 4.2. РEГ } \\
\text { 4.2. REG }\end{array}$} & \multirow{3}{*}{$\begin{array}{l}\text { Обеспеченность и доступность социальных учреждений } \\
\text { (отношение «Всего мест в стационарных учреждениях } \\
\text { социального обслуживания для граждан пожилого воз- } \\
\text { раста и инвалидов (взрослых)» к общей численности } \\
\text { населения, находящегося в возрасте старше трудоспо- } \\
\text { собного), \% } \\
\text { Provision and accessibility of social institutions (the ratio of } \\
\text { «Total places in inpatient social service institutions for el- } \\
\text { derly citizens and disabled people (adults)» to the population } \\
\text { over the working age), \% }\end{array}$} & 2014 & 71,62 & 83,23 \\
\hline & & 2016 & 70,01 & 79,28 \\
\hline & & 2018 & 69,2 & 73,91 \\
\hline \multirow{3}{*}{$\begin{array}{l}\text { 4.3. РЕГ } \\
\text { 4.3. REG }\end{array}$} & \multirow{3}{*}{$\begin{array}{l}\text { Средняя обеспеченность социально-денежными выпла- } \\
\text { тами лиц старшего поколения (рассчитывается как ис- } \\
\text { полнение расходных обязательств в рублях на пенсионе- } \\
\text { ров, ветеранов, тружеников тыла к численности населе- } \\
\text { ния, находящегося в возрасте старше трудоспособного), } \\
\text { р. } \\
\text { Average provision of social and monetary payments to the } \\
\text { older generation (calculated as the fulfillment of expenditure } \\
\text { obligations in rubles for pensioners, veterans, home front } \\
\text { workers to the population older than the able-bodied popula- } \\
\text { tion), rubles }\end{array}$} & 2014 & 4783,67 & 3257,89 \\
\hline & & 2016 & 4981,34 & 3008,2 \\
\hline & & 2018 & 5145,45 & 2675,04 \\
\hline \multirow{3}{*}{$\begin{array}{l}\text { 4.4. РЕГ } \\
\text { 4.4. REG }\end{array}$} & \multirow{3}{*}{$\begin{array}{l}\text { Положительное мнение о проживании в населенном } \\
\text { пункте, доля ответов «Да», \% } \\
\text { Positive opinion about living in the place of residence, the } \\
\text { share of «Yes» answers, \% }\end{array}$} & 2014 & 94,84 & 96,77 \\
\hline & & 2016 & 93,9 & 90 \\
\hline & & 2018 & 94,91 & 90,39 \\
\hline \multirow{3}{*}{$\begin{array}{l}\text { 4.5. PEГ } \\
\text { 4.5. REG }\end{array}$} & \multirow{3}{*}{$\begin{array}{l}\text { Наличие проблем в населенном пункте, доля ответов } \\
\text { «Нет», \% Problems in the place of residence, share of «No» } \\
\text { answers, \% }\end{array}$} & 2014 & 73,33 & 78,25 \\
\hline & & 2016 & 73,12 & 73,78 \\
\hline & & 2018 & 76,01 & 77,98 \\
\hline \multirow{3}{*}{$\begin{array}{l}\text { 4.6. РЕГ } \\
\text { 4.6. REG }\end{array}$} & \multirow{3}{*}{$\begin{array}{l}\text { Отсутствие проблем в сфере медицинского обслужива- } \\
\text { ния в населенном пункте, доля ответов «Нет», \% } \\
\text { Absence of problems in the field of medical care in the place } \\
\text { of residence, the share of «No» answers, \% }\end{array}$} & 2014 & 77,25 & 80,65 \\
\hline & & 2016 & 75,66 & 85,71 \\
\hline & & 2018 & 77,17 & 83,33 \\
\hline
\end{tabular}

Примечание. *Для Томской области много пропущенных значений, поэтому данный индикатор не отражает реальную картину.

Note. *There are many missing values for Tomsk Oblast, therefore this particular indicator does not reflect the real picture.

Анализ показал, что по отдельным ненормализованным показателям в доменах РИБСП Томская область имеет смешанную динамику. Рассмотрим более детально изменение значений индекса для Томской области по сравнению со среднероссийскими по домену «Экономика». В 2014 г. Томская область опережала среднероссийские показатели в этой сфере:

- по соотношению среднего размера назначенных пенсий и величины прожиточного минимума (на 9,8\%);

- наличию у пожилых людей оплачиваемой работы или доходного занятия (на 8,5 \%);

- реальному размеру назначенных пенсий (на 0,6 \%).

Незначительное отставание (на 1,7 \%) от среднероссийского уровня в домене «Экономика» у Томской области было по степени удовлетворенности пожилых людей работой, (показателю, рассчитываемому по восьми специальным параметрам). Из всех показателей, входящих в домен «Экономика», в 2014 г. Томская область в наибольшей степени отставала от среднероссийских значений по уровне занятости граждан в возрасте, выше трудоспособного (на 4,7 \%). 
В 2016 г. ситуация в Томской области в данной сфере изменилась к худшему. В этот период Томская область опережала среднероссийский уровень только по соотношению среднего размера назначенных пенсий и величины прожиточного минимума (на 8,3 \%). Почти совпало обобщенное мнение работающих пожилых людей в Томской области со среднероссийским о наличии у них оплачиваемой работы, а по трем остальным показателям этого домена Томская область не достигла среднероссийских значений:

- уровень занятости пожилых людей оказался ниже общероссийского на 5,9 \%;

- степень удовлетворенности работой - на 4,32\%;

- реальный размер назначенных пенсий - на 3,7 \%.

В 2018 г. ситуация по домену «Экономика» в Томской области продолжила свое негативное развитие (рис. 3). В этот период Томская область по-прежнему опережала среднероссийский уровень только по соотношению среднего размера назначенных пенсий и величины прожиточного минимума (на 13,8 \%). Почти совпали показатели Томской области со среднероссийскими по реальному размеру пенсий. А по трем остальным показателям этого домена Томская область не достигла среднероссийских значений:

- уровень занятости пожилых людей оказался ниже общероссийского на 9,1%;

- степень удовлетворенности работой - на 3,93 \%;

- наличие у пожилых людей оплачиваемой работы - на 2,42 \%.

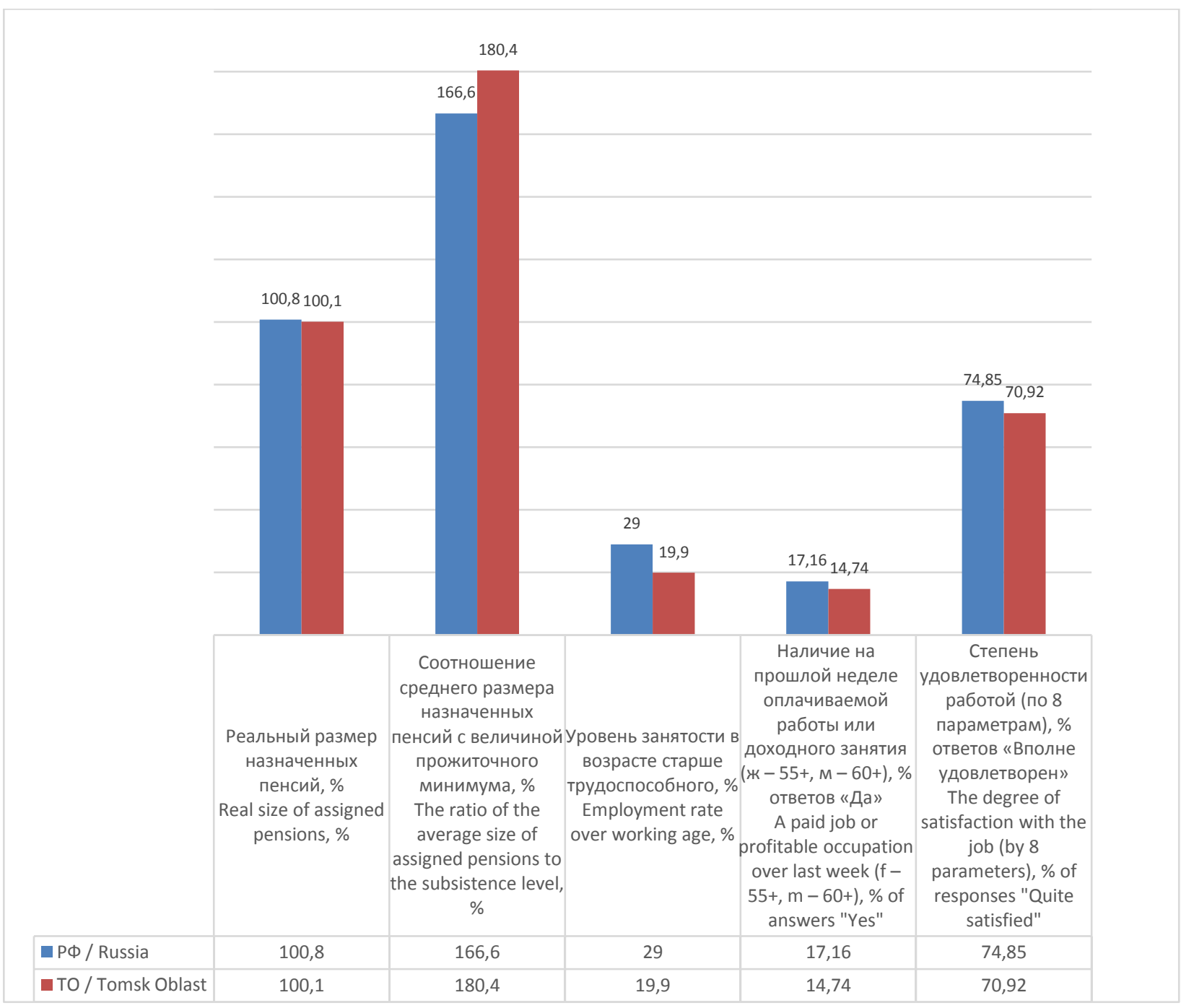




\section{Puc. 3. Значения отдельных индикаторов домена «Экономика» по РФ в целом и в Томской области, 2018 г.}

Fig. 3. Particular indicator values for domain «Economy» in Russia and in Tomsk Oblast, 2018

Если совместить анализ динамики значении в домене «Экономика» РИБСП для Томской области с актуальными данными официальной статистики по Томской области (табл. 2), то подтверждается предварительный вывод о том, что ухудшение рейтинга региона связано скорее не с его собственной экономической динамикой, она вполне благоприятна, а с лучшей динамикой изменений в других регионах страны.

Таблица 2. Основные социально-экономические индикаторы уровня жизни населения Томской области [19]

Table 2. Principal socioeconomic level of life indicators in Tomsk Oblast [19]

\begin{tabular}{|l|c|c|c|c|c|}
\hline \multicolumn{1}{|c|}{ Показатели/Indicators } & 2016 & 2017 & 2018 & 2019 & 2020 \\
\hline $\begin{array}{l}\text { Средний размер назначенных пенсий, p. } \\
\text { Average size of assigned pensions, rubles }\end{array}$ & 13614 & 14552 & 15357 & 16216 & 17107 \\
\hline $\begin{array}{l}\text { Величина прожиточного минимума для пенсионеров, p. } \\
\text { Value of the subsistence minimum for pensioners, rubles }\end{array}$ & 8557 & 8604 & 8718 & 9255 & 9618 \\
\hline $\begin{array}{l}\text { Реальный размер назначенных пенсий, \% к предыдущему } \\
\text { году } \\
\text { Real amount of assigned pensions, \% of the previous year }\end{array}$ & 97,7 & 104,4 & 100,1 & 102,4 & 101,2 \\
\hline $\begin{array}{l}\text { Соотношение с величиной прожиточного минимума сред- } \\
\text { него размера назначенных пенсий, \% } \\
\text { Correlation of the average size of assigned pensions with the } \\
\text { value of the subsistence minimum, \% }\end{array}$ & 165,3 & 175,0 & 180,4 & 179,6 & 179,3 \\
\hline
\end{tabular}

Анализ показателей, характеризующих благополучие пожилых людей в Томской области в домене «Социум», приводит к следующим выводам. В 2014 г. Томская область уверенно опережала среднероссийский уровень образованности пожилых. Доля граждан старшего возраста в Томской области с высшим образованием превышала среднероссийское значение на 3,18 \%. Примерно на среднероссийском уровне было значение показателя, характеризующего долю пожилых людей среди пользователей сети Интернет. При этом по трем показателям этого домена значения в Томской области оказались ниже, чем среднероссийские:

- показатель, характеризующий посещение досуговых мероприятий, оказался в Томской области ниже общероссийского на 7,3 \%;

- помощь детей, проживающих отдельно, - на 6,93%;

- членство пожилых людей в добровольных организациях - на 0,84 \%.

Аналогичные значения по данным за 2016 г. приводят к выводам о том, что несмотря на рост абсолютных значений по отдельным показателям (в сравнении с 2014 г.), Томская область в этом аспекте ухудшила свои рейтинговые значения. Отметим, что параметр, характеризующий долю респондентов в Томской области с высшим образованием, в данном домене оказался практически на уровне среднероссийского. Однако следует учесть большое количество пропущенных ответов респондентов на этот вопрос в 2016 г., что явно занизило его объективную оценку, учитывая исторически высокий уровень образования населения в Томской области в целом.

Тем не менее по всем остальным показателям, включенным в домен «Социум», в 2016 г. в Томской области наблюдается негативная рейтинговая динамика: 
- показатель, характеризующий помощь детей, проживающих отдельно, оказался ниже среднероссийского на $10,14 \%$;

- посещение досуговых мероприятий - на 9,7 \%.

- доля пожилых в общем числе пользователей сети Интернет - на 1,6 \%;

- членство пожилых в добровольных организациях - на 1,5 \%.

Анализ аналогичных данных за 2018 г. отражает нарастание в Томской области негативной динамики показателей в домене «Социум» (рис. 4). Показатели этого домена отражают способность пожилого человека вмещать в свою жизнь те аспекты окружающего мира, которые связаны с культурой, политикой, изменением к лучшему общественного устройства и развитием самого себя. Именно социальные связи, а не занятость, все чаще выделяются исследователями как приоритет пожилых людей для самореализации [20]. Индикаторы данного домена отражают различные грани социальной среды, социальную инклюзию пожилых [21], а также показывают, что именно эту среду определяет, делает ее привлекательной и дружественной для пожилых людей, адаптированной к их запросам [21]. В анализируемом периоде Томская область достигла среднероссийских значений лишь по членству пожилых людей в добровольных организациях. При этом отметим, что основными мотивами участия в добровольческой деятельности людей старшего возраста традиционно выступают желание почувствовать себя компетентным, поддержка контактов с людьми, разумное использование свободного времени [22]. Есть исследования, подтверждающие и другие мотивы «серебряных волонтеров». Среди них стремление: 1) поддержать интенсивную активность; 2) поработать и пообщаться с энергичной молодежью; 3) поучаствовать в резонансных событиях; 4) внести вклад в саморазвитие; 5) расширить круг и повысить качество общения; 6) использовать доступные ресурсы; 7) помочь нуждающимся [23]. Не менее важно для пожилых волонтеров реализовать потребность бескорыстно участвовать в жизни других людей, дарить им свою любовь [23].

В данном домене было решено признать показатель, характеризующий образование граждан старшего возраста в Томской области, на уровне не ниже среднероссийского (по тем же причинам, что и в 2016 г.). А по остальным трем показателям Томская область вновь показала значения хуже, чем среднероссийские:

- показатель, характеризующий помощь детей, проживающих отдельно, оказался ниже среднероссийского на 7,9\%;

- посещение досуговых мероприятий - на 15,59\%.

- доля пожилых в общем числе пользователей сети Интернет - на 3,9 \%.

Анализ показателей, включенных в домен «Здоровье» и характеризующих позиции Томской области относительно среднероссийского уровня, показал следующее. В 2014 г. Томская область продемонстрировала превышение таких среднероссийских показателей, как возможность пожилыми людьми вести активную жизнь (на 7,75 \%) и самооценка состояния здоровья (на 1,21\%). Примерно на среднероссийском уровне Томская область оказалась по ожидаемой предстоящей продолжительности жизни у мужчин и женщин, а по трем остальным параметрам Томская область показала значения ниже, чем средние по России:

- по отсутствию хронических заболеваний, установленных врачом, - на 3,41%;

- доле некурящих - на 3,96 \%;

- доле непьющих - на 3,49\%.

В 2016 г. ситуация изменилась. Томская область незначительно превзошла здесь лишь один среднероссийский показатель этого домена - возможность пожилых людей вести активную жизнь (на 1,65 \%), по ожидаемой предстоящей продолжительности 
жизни женщин оказалась на среднероссийском уровне, а по всем остальным параметрам показала значения хуже, чем в среднем по РФ:

- по ожидаемой предстоящей жизни мужчин - на 2,76 месяца;

- отсутствию хронических заболеваний, установленных врачом, - на 9,55 \%;

- доле некурящих - на 2,51 \%;

- самооценке состояния здоровья - на 2,22 \%;

- по доле непьющих - на 0,71\%.

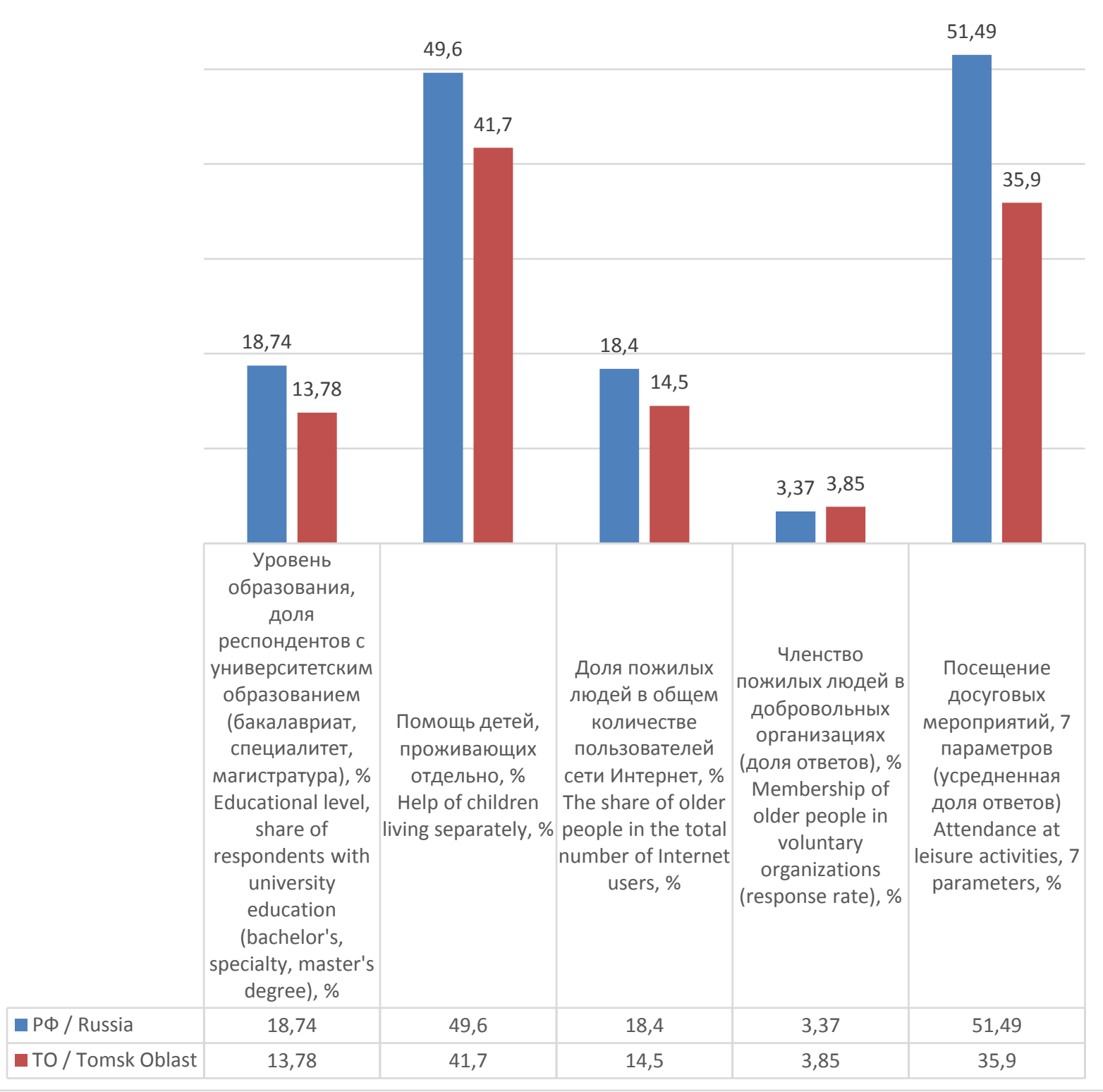

Puc. 4. Значения отдельных индикаторов домена «Социум» по РФ в целом и в Томской области, 2018 г.

Fig. 4. Particular indicator values for domain «Social» in Russia and in Tomsk Oblast, 2018

В 2018 г. ситуация продолжила изменяться к худшему (рис. 5). Томская область не превзошла ни один среднероссийский показатель этого домена, но вышла на среднерос- 
сийские значения по трем показателям этой группы: по ожидаемой предстоящей продолжительности жизни мужчин и женщин, а также по возможности пожилых людей вести активную жизнь. По остальным четырем параметрам Томская область показала значения хуже, чем в среднем по РФ:

- по доле некурящих - на 5,36 \%;

- самооценке состояния здоровья - на 4,42 \%;

- отсутствию хронических заболеваний, установленных врачом - на 3,61%;

- доле непьющих - на 2,48 \%.

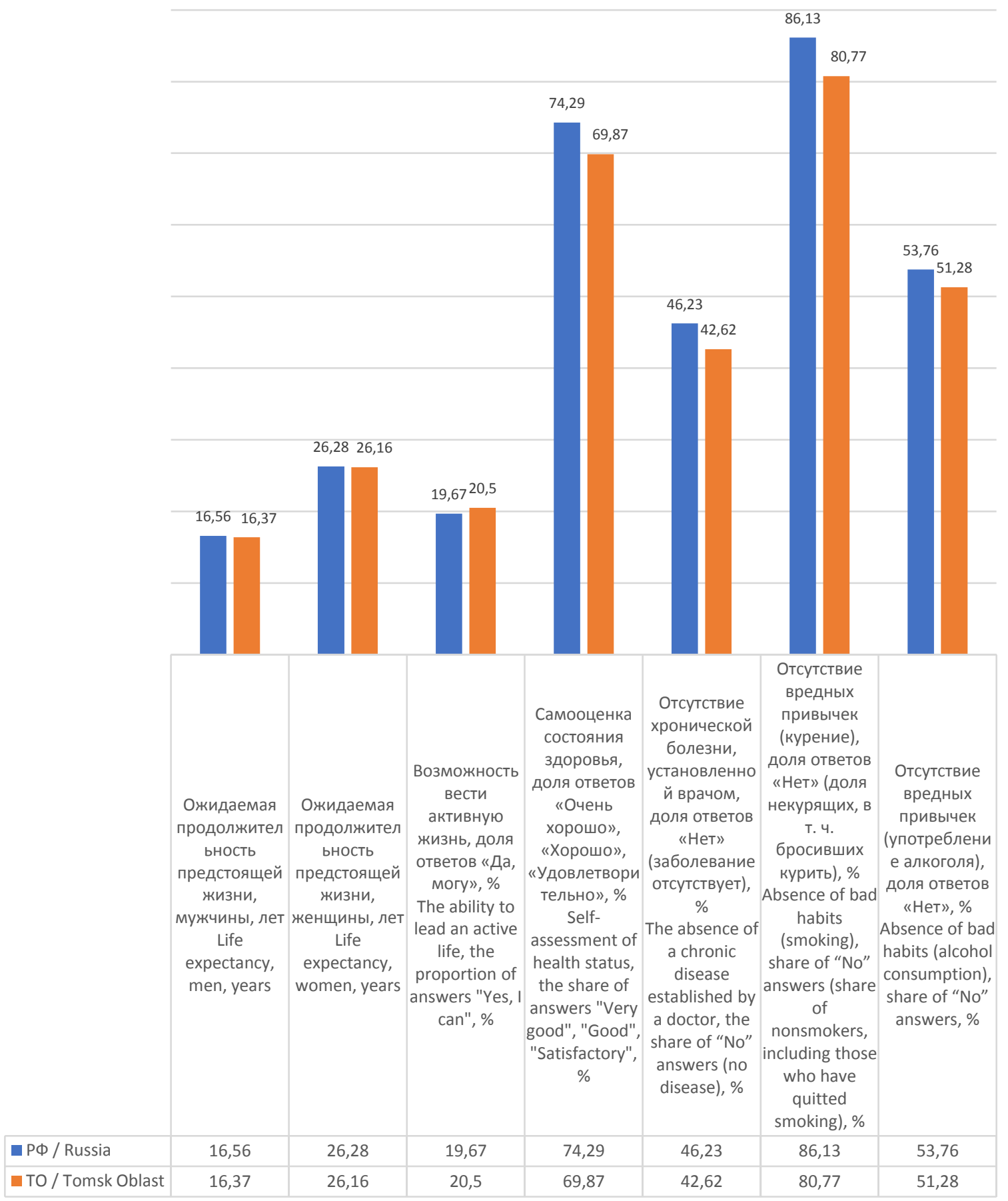




\section{Pис. 5. Значения отдельных индикаторов домена «Здоровье» по РФ в целом и в Томской области, 2018 г.}

Fig. 5. Particular indicator values for domain «Health» in Russia and in Tomsk Oblast, 2018

Анализ показателей, включенных в домен «Регион» и характеризующих позиции Томской области относительно среднероссийского уровня, показал следующее. В 2014 г. Томская область превосходила четыре среднероссийских показателя в этой сфере:

- по обеспеченности и доступности социальных учреждений - на 11,61%;

- отсутствию проблем в населенном пункте - на 4,92 \%;

- отсутствию проблем в сфере медицинского обслуживания - на 3,4%;

- положительному мнению, о проживании в населенном пункте - на 1,93 \%.

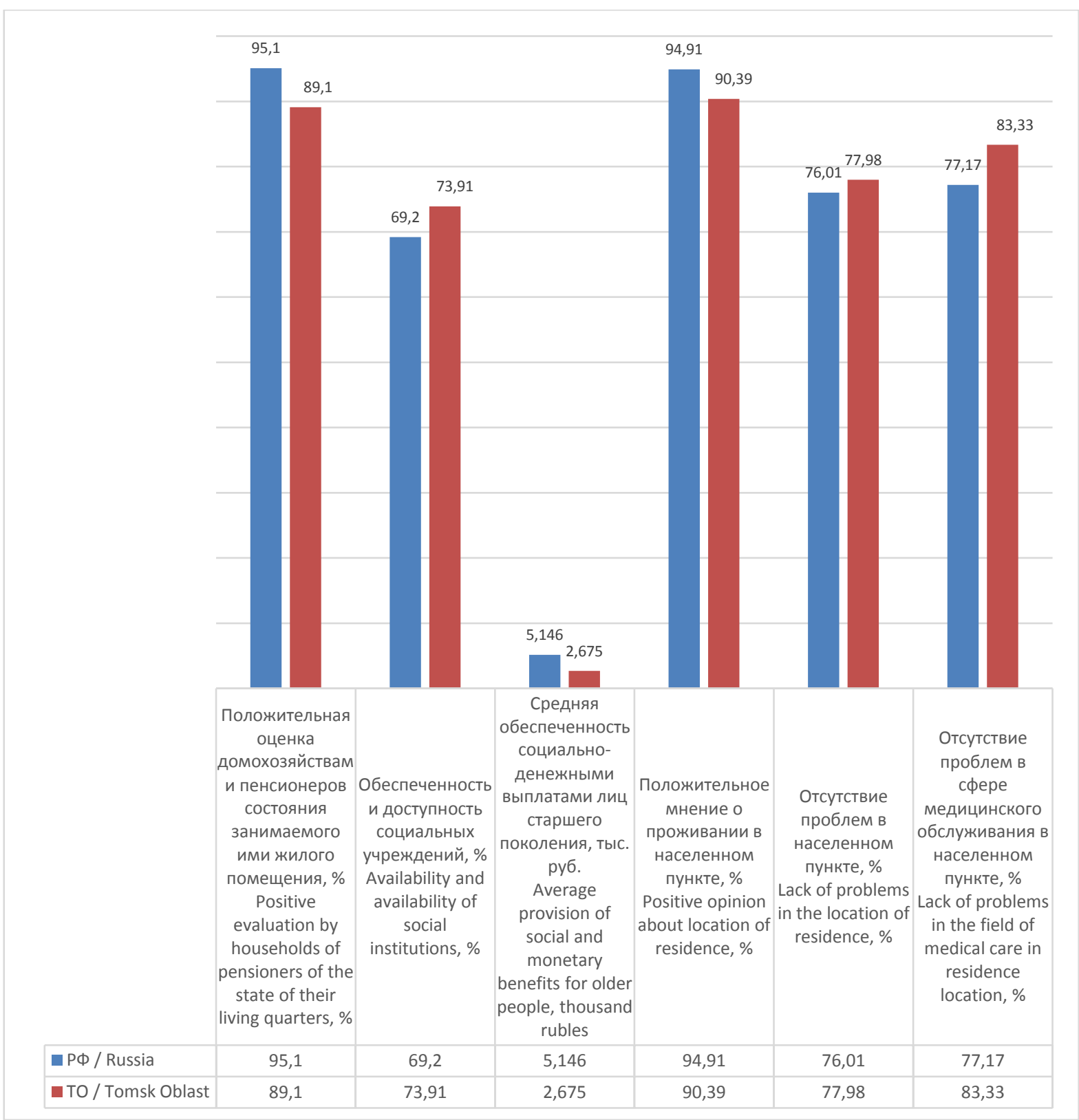




\section{Puc. 6. Значения отдельных индикаторов домена «Регион» по РФ в целом и в Томской области, 2018 г.}

Fig. 6. Particular indicator values for domain «Region» in Russia and in Tomsk Oblast, 2018

По двум показателям этого домена Томская область отставала от среднероссийских значений: 1) по положительной оценке домохозяйством, в котором поживает пенсионер, состояния занимаемого жилого помещения - на $1,3 \%$; 2) по средней обеспеченности социально-денежными выплатами (которая рассчитывается как отношение суммы исполненных расходных обязательств в рублях на пенсионеров, ветеранов, тружеников тыла к численности населения, находящегося в возрасте старше трудоспособного). Здесь отставание от среднероссийского значения составило 1526 руб.

В 2016 г. ситуация была несколько иная. Томская область превосходила среднероссийский значения только по двум параметрам этого домена и с другим отрывом:

- по обеспеченности и доступности социальных учреждений - на 9,27 \%;

- отсутствию проблем в сфере медицинского обслуживания - на 8,5 \%.

Значение параметра «отсутствие проблем в населенном пункте» было в 2016 г. на среднероссийском уровне.

Значения трех показателей этого домена в 2016 г. были хуже, чем в среднем по России:

- положительная оценка домохозяйствами пенсионеров состояния занимаемого ими жилого помещения - на 4,4 \%;

- положительное мнение о проживании в населенном пункте - на 3,9 \%;

- средняя обеспеченность социально-денежными выплатами - на 1973 руб.

В 2018 г. ситуация в Томской области менялась неоднозначно (рис. 6). Томская область превосходила среднероссийский значения по трем параметрам этого домена:

- по обеспеченности и доступности социальных учреждений - на 4,71 \%;

- отсутствию проблем в населенном пункте - на 1,97 \%;

- отсутствию проблем в сфере медицинского обслуживания - на 6,16 \%.

Значения трех показателей этого домена в 2018 г. были хуже, чем в среднем по России:

- положительная оценка домохозяйствами пенсионеров состояния занимаемого ими жилого помещения - на $6 \%$;

- положительное мнение о проживании в населенном пункте - на 4,52 \%;

- средняя обеспеченность социально-денежными выплатами - на 2471 руб.

\section{Анализ динамики позиций Томской области в рейтинге РИБСП за 2014, 2016, 2018 гг. по отдельным доменам}

К описанию динамики позиций Томской области в разрезе сравнения показателей отдельных доменов со среднероссийскими целесообразно добавить анализ динамики абсолютных значений рассматриваемых показателей, характерных для Томской области по данным за 2014, 2016 и 2018 гг.

Так, по индикаторам, отнесенным к домену «Экономика», Томская область не продемонстрировала устойчивой динамики ни по одному из направлений (рис. 7). При этом по двум (уровень занятости в возрасте старше трудоспособного и наличию у пожилых людей оплачиваемой работы) наблюдается устойчивое снижение по трем периодам 
наблюдений. 2018 г. в целом стал провальным практически по всем экономическим показателям (в сравнении с довольно благоприятной ситуацией в 2016 г.), причем показатель степени удовлетворённости пожилых людей работой в 2018 г. оказался даже ниже, чем в 2014-м.

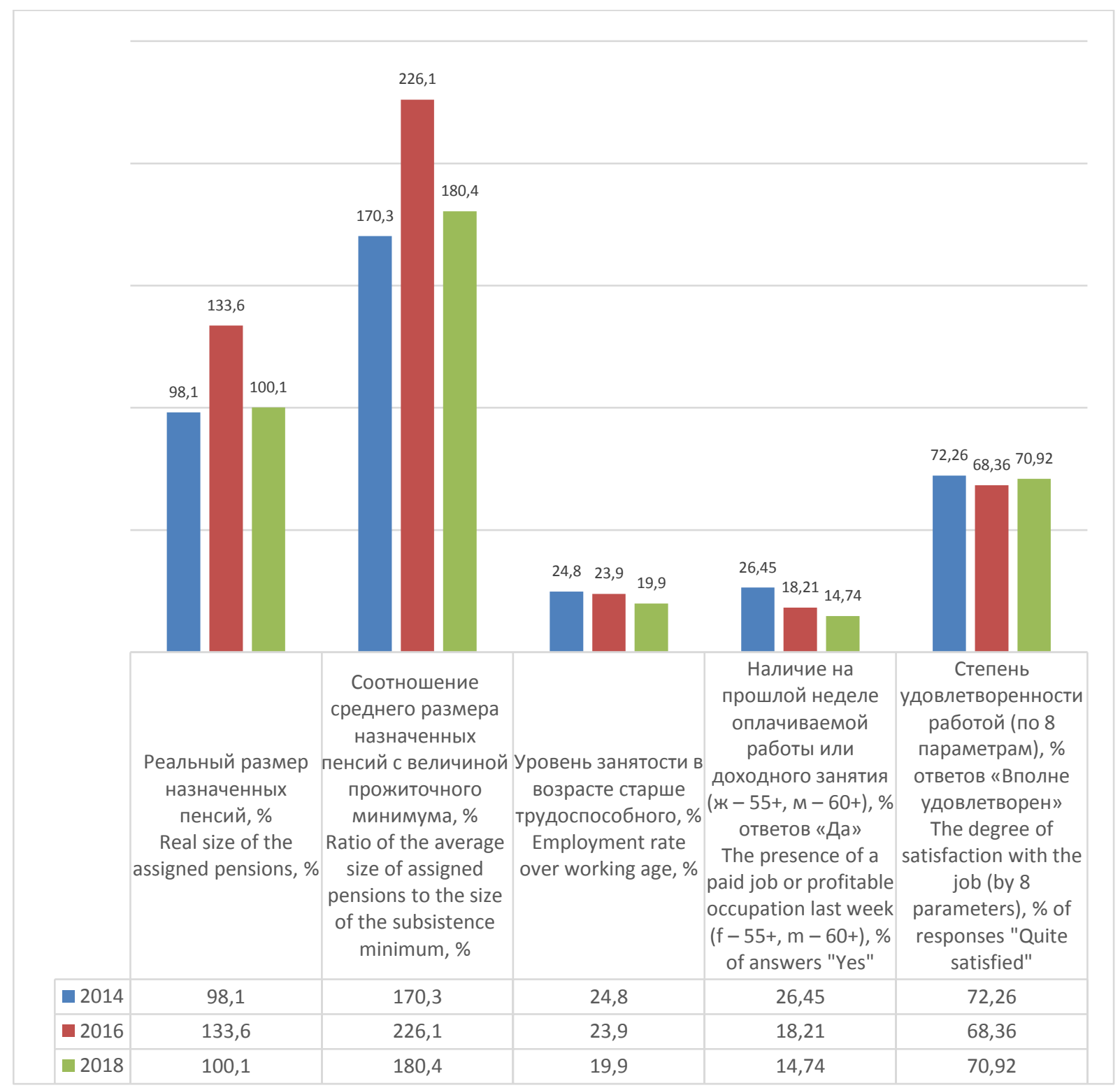

Pис. 7. Динамика отдельных индикаторов в домене «Экономика» для Томской области в 2014, 2016, 2018 г2.

Fig. 7. Dynamics of particular indicator values for domain «Economy» in Tomsk Oblast, 2014, 2016, 2018

Динамику абсолютных значений Томской области в домене «Социум» следует признать более благоприятной (рис. 8). С учетом замечаний, высказанных ранее об ответах респондентов, которые характеризуют их уровень образования, динамику по этому параметру не следует считать негативной. В рассматриваемых периодах активизировалась помощь пожилым людям со стороны детей, поживающих отдельно, среди пожилых людей выросла доля активных пользователей Интернета и последовательно возрастало их 
участие добровольных организациях. Отрицательная динамика в рассматриваемых периодах была лишь у индикатора, характеризующего посещение пожилыми людьми досуговых мероприятий.

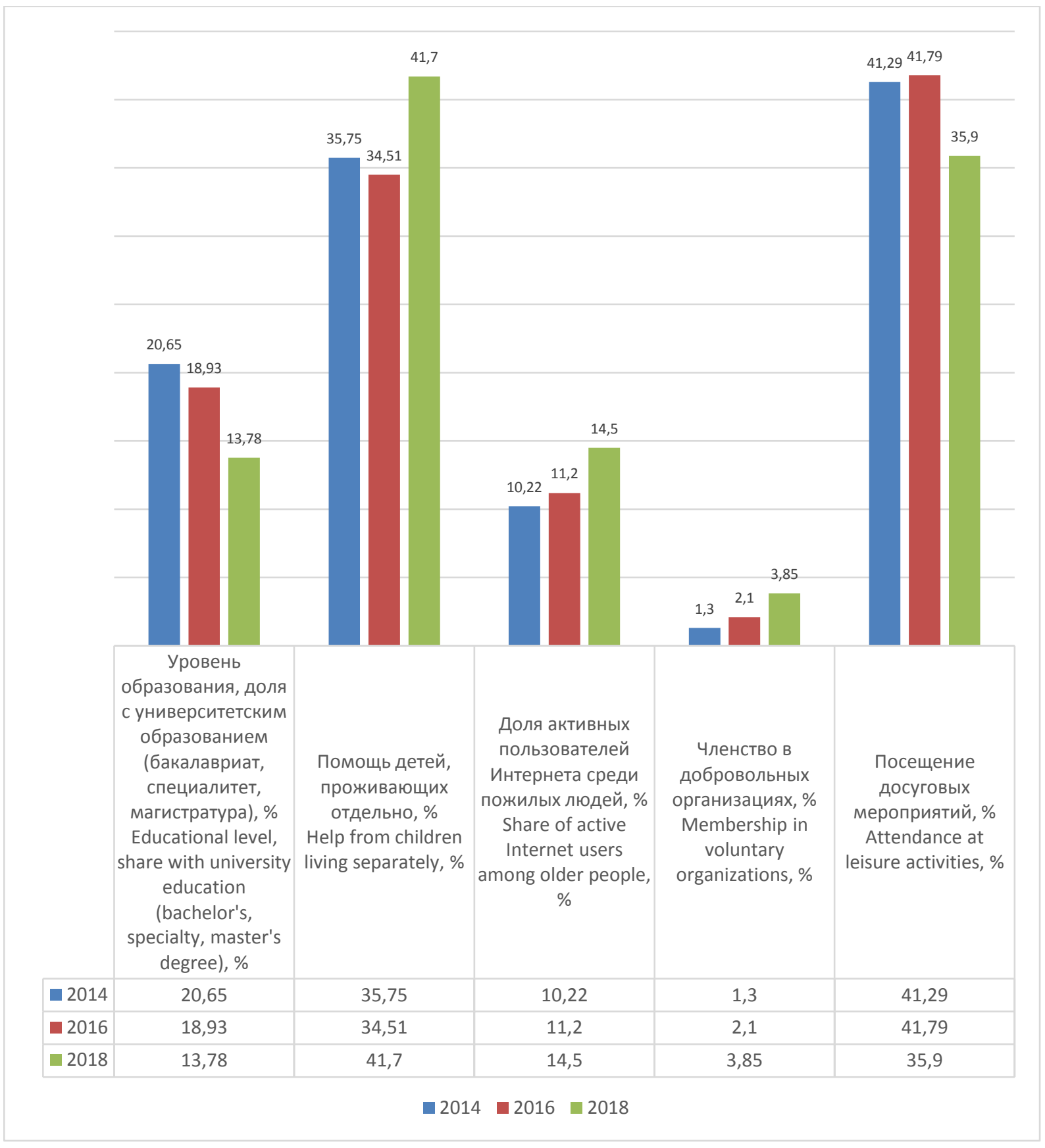

Pис. 8. Динамика отдельных индикаторов в домене «Социум» для Томской области в 2014, 2016, 2018 г2.

Fig. 8. Dynamics of particular indicator values for domain «Social» in Tomsk Oblast, 2014, 2016, 2018

У большинства индикаторов, отнесенных к домену «Здоровье» практически нет ни положительной, ни отрицательной динамики за рассматриваемые периоды наблюдений (рис. 9). Однако, безусловно, положительно здесь следует оценивать последовательный 
прирост ожидаемой продолжительности предстоящей жизни как у мужчин, так и у женщин, при этом гендерная дифференциация этих показателей выглядит весьма тревожно.

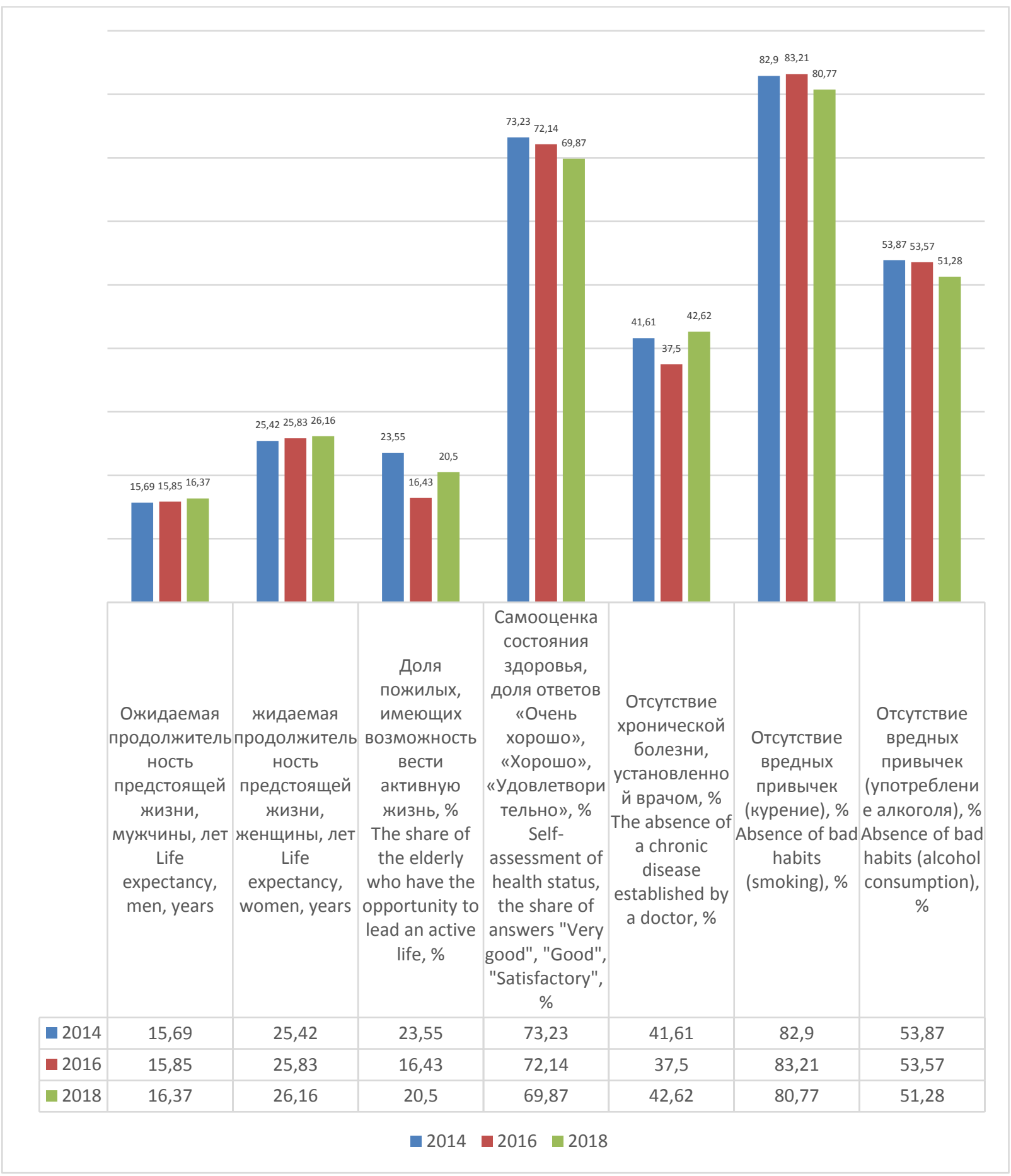

Рис. 9. Динамика отдельных индикаторов в домене «Здоровье» для Томской области в 2014, 2016, 2018 г2.

Fig. 9. Dynamics of particular indicator values for domain «Health» in Tomsk Oblast, 2014, 2016, 2018 
Самая негативная динамика за рассматриваемый период наблюдений была выявлена у тех индикаторов Томской области, которые отнесены к домену «Регион» (рис. 10).

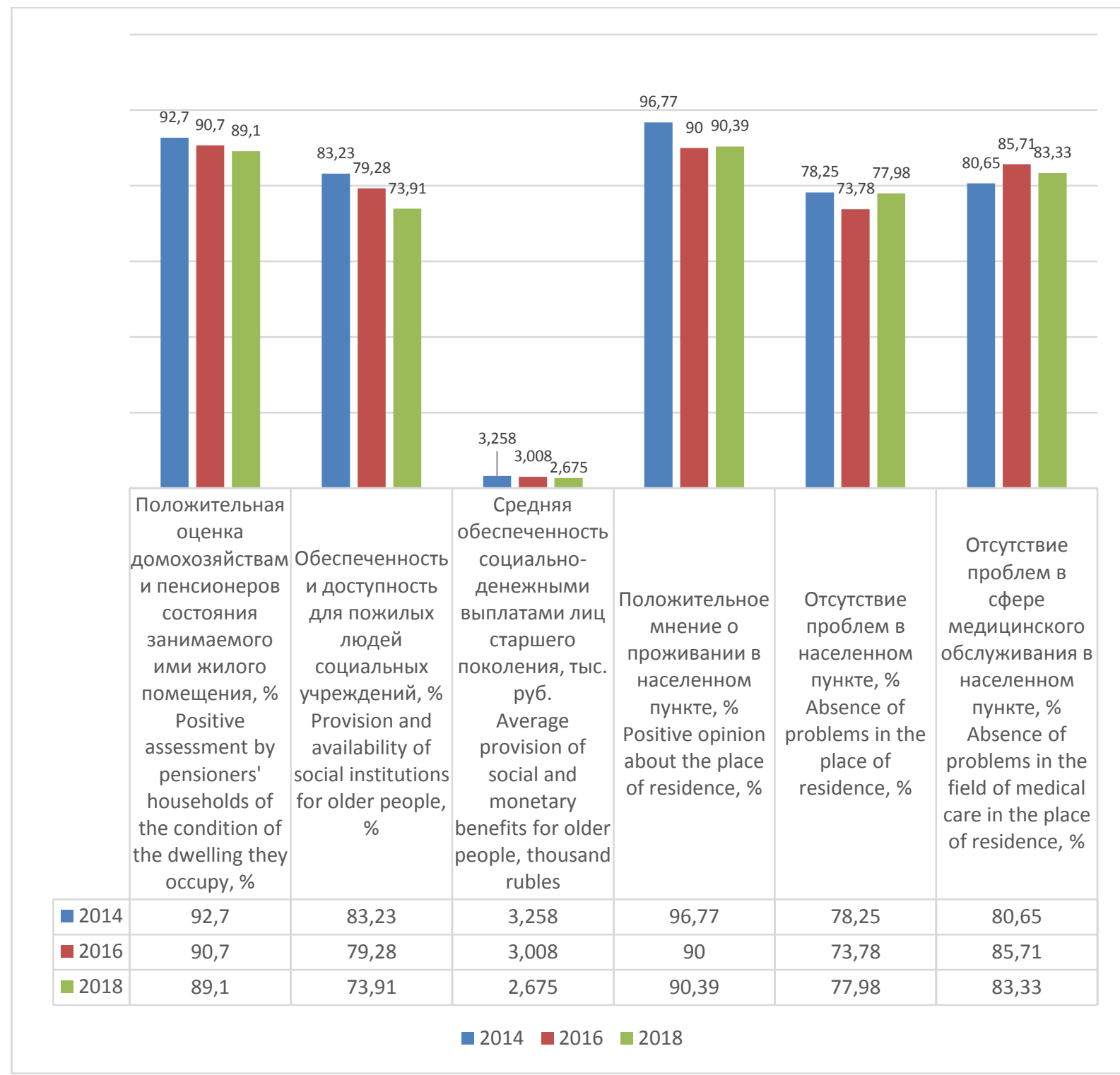

Рис. 10. Динамика отдельных индикаторов в домене «Регион» для Томской области в 2014, 2016, 2018 г2.

Fig. 10. Dynamics of particular indicator values for domain «Region» in Tomsk Oblast, 2014, 2016, 2018

Практически все абсолютные значения в каждом из периодов наблюдений в данном домене последовательно снижались. Особенно критично здесь выглядит снижение за весь период наблюдений средней обеспеченности пожилых людей социальными выплатами (всего на 18 \%), а также последовательное снижение доли пожилых, довольных состоянием своего жилища и степенью доступности социальных учреждений.

\section{Выводы и заключение}


Как известно, индексный метод оценки часто вызывает критику по причине особенностей методологии, а также ограниченности применения математических инструментов при его формировании. Поскольку любой интегральный (композитный) индекс включает в себя множество разнородных индикаторов, которые описывают разнородные процессы, процесс формирования композитного индекса неизбежно усложняется. С другой стороны, не стоит недооценивать преимущества индексов: их интегральные расчётные значения облегчают работу разнообразным стейкхолдерам при анализе соответствующих процессов, они незаменимы при разработке программ и мер поддержки, направленных на решение конкретных проблем.

В случае с РИБСП при оценке качества жизни и благополучия старшего поколения рекомендуется критически подходить к его применению:

- РИБСП позволяет комплексно оценивать положение региона относительно других субъектов РФ, т. к. интегральное значение индекса - это все же относительный показатель. Однако данная оценка является значимой при выявлении динамики конкретного региона в макроусловиях, которые одинаковы для всех субъектов РФ;

- РИБСП можно использовать для анализа разных временных периодов для одного и того же субъекта РФ для отслеживания трендов: 1) повышательный (положительный, позитивный и т. д.); 2) понижательный (отрицательный, негативный и т. д.); 3) нейтральный;

- для более глубокого анализа и выявления причинно-следственной связи положительных или отрицательных изменений рекомендуется рассматривать ненормализованные значения отдельных индикаторов индекса (дезагрегированные данные) и проводить сравнения со среднероссийскими значениями, а также со значениями референтных регионов;

- анализ изменений позиции конкретного региона в общем рейтинге РИБСП рекомендуется дополнять другими индикаторами для сопоставления субъективных оценок (индикаторов РИБСП, рассчитанных на основе КОУЖ). На первоначальном этапе разработки индекса была проведена оценка качества индикаторов на основе исследования КОУЖ.

Переменные с небольшим количеством респондентов и большим количеством пропущенных данных изначально исключались из возможного списка используемых данных. Ключевым требованием к переменным КОУЖ было достаточное количество респондентов/ответов (открытые данные) с возможностью расчета индекса для всех субъектов РФ. Однако несмотря на соблюдение методической процедуры разработки индекса, можно наблюдать сомнительные результаты по отдельному индикатору, как в случае Томской области это произошло с уровнем образования.

В целом сделанное ранее предположение, что сохранение регионом от года к году тех же самых рейтинговых значений, в случае Томской области, не следует рассматривать в положительном ключе. Анализ показал, что за этим, скорее всего, стоит неспособность региона оперативно и эффективно адаптироваться к происходящим макроизменениям. Учитывая тот факт, что по ряду индикаторов различных доменов Томская область не только не сохранила достигнутые в 2014 г. значения, но и ухудшила их, следует говорить скорее не о нейтральном сценарии ее развития, а о замедлении его темпов и, возможно, о стагнации. Учитывая существенную положительную динамику по анализируемым индикаторам в других регионах, полученные выводы требуют детального обсуждать и выявления конкретных причин, обусловивших замедление или негативную динамику процессов в Томской области, которые описываются отдельными показателями. 
Несмотря на определенные ограничения при разработке РИБСП и требования к данным индекса (открытые данные с разбивкой для всех регионов РФ), структура индекса концептуально следует методологическим процедурам разработки международных индексов по оценке качества жизни и благополучия. Также структуру индекса можно рассматривать в институциональном ключе через концепцию «институциональных сфер» [25]. РИБСП включает в себя индикаторы оценки ресурсного потенциала в домене «Экономика» (доход, занятость, удовлетворенность работой), «Социум» (образование, социальные связи, досуг, добровольческую деятельность), «Здоровье» (продолжительность жизни, самооценка здоровья, хронические болезни и вредные привычки, которые характеризуют потенциал здоровья). Домен «Региональное пространство» охватывает качество институциональной среды региона и ее физической инфраструктуры (качество жилья, доступность социальных и медицинских учреждений, социальные трансферты, качество физической инфраструктуры и безопасность места проживания). Многие индикаторы этого домена являются субъективными оценками, которые отражают мнение представителей старшего возраста относительно качества среды в месте проживания.

Индикаторы РИБСП в целом и домена «Региональное пространство» можно в целом сравнить с подходом Active Ageing Index, когда оценивается ресурсный потенциал старшего поколения по двум направлениям: 1) реализация ресурсного потенциала скорее зависит напрямую от индивида; 2) реализация ресурсного потенциала зависит от среды (enabling environment) - насколько благоприятной, дружественной, безопасной и ориентированной на старшее поколение являются институциональная среда и физическая инфраструктура места проживания.

Выводы, полученные авторами при анализе значений РИБСП за 2014, 2016 и 2018 гг. говорят не только о наличии множества нерешенных проблем в рассматриваемой сфере. Они отражают значительные разрывы между официально провозглашенными намерениями государства по повышению качества жизни старшего поколения и реальным положением дел, что весьма явно проявляется в динамике доменов РИБСП для страны в целом и в значениях отдельных индикаторов данного индекса для Томской области.

Есть надежда на изменение сложившейся ситуации при внедрении Российского индекса активного долголетия. Благодаря расчету в соответствии с международной методологией, возможностям для анализа на уровне Российской Федерации и ее субъектов, в том числе в гендерном разрезе, РИАД будет не только официально признанным инструментом мониторинга социальной политики в отношении граждан старшего поколения, но и основанием для принятия решений, способных привести к заметному прогрессу в рассматриваемой сфере.

Исследование выполнено при финансовой поддержке Российского научного фонда в рамках научноисследовательского проекта «Институты реализации ресурсного потенциала старшего поколения в экономике старения» (проект № 19-18-00300).

\section{СПИСОК ЛИТЕРАТУРЫ}

1. О национальных целях развития Российской Федерации на период до 2030 года: указ Президента РФ. URL: http://www.kremlin.ru/events/president/news/63728 (дата обращения 25.07.2021).

2. Павлова И.А., Недоспасова О.П. Институциональные функции в анализе ресурсного потенциала старшего поколения // Региональная экономика: теория и практика. - 2021. - Т. 19. - № 5 (488). C. $972-1002$.

3. Active Ageing Index. URL: https://unece.org/population/active-ageing-index (дата обращения 25.07.2021).

4. Active Ageing Index Analytical Report 2019. URL: https://unece.org/info/Population/pub/2804 (дата обращения 26.07.2021). 
5. Global Age Watch Insights 2018. URL: https://www.helpage.org/resources/publications/?ssearch=Global+ AgeWatch $+\& a d v=0 \&$ topic $=0 \&$ region=0\&language $=0 \&$ type $=0$ (дата обращения 27.07.2021).

6. 2002 Madrid International Plan of Action on Aging. URL: https://www.un.org/ru/ documents/decl_conv/declarations/ageing_program.shtml (дата обращения 08.10.2021).

7. Стратегия действий в интересах граждан старшего поколения в Российской Федерации до 2025 года // Официальный сайт Министерства труда и социального развития РФ. URL: https://mintrud.gov.ru/ministry/programms/37/2 (дата обращения 17.09.2021).

8. Национальный проект «Демография» // Официальный сайт Министерства труда и социального развития РФ. URL: https://mintrud.gov.ru/ministry/programms/demography (дата обращения 06.09.2021).

9. Федеральный проект «Старшее поколение» // Официальный сайт Министерства труда и социального развития РФ URL: https://mintrud.gov.ru/ministry/programms/demography/3 (дата обращения 28.07.2021).

10. Концепция политики активного долголетия: научно-методологический доклад к XXI Апрельской международной научной конференции по проблемам развития экономики и общества / Л.Н. Овчарова, М.А. Морозова, А.В. Сидоренко и др. - М.: Изд. дом Высшей школы экономики, 2020. - 40 с.

11. Об утверждении методики расчета Индекса активного долголетия в Российской Федерации № 634 от 31 октября 2019 г.: приказ Федеральной службы государственной статистики Министерства экономического развития РФ. URL: https://docs.cntd.ru/document/563664925 (дата обращения 08.10.2021).

12. Российский индекс благополучия старшего поколения: методология, методика, апробация // Журнал исследований социальной политики / И.А. Павлова, Е.А. Монастырный, И.В. Гуменников, Г.А. Барышева. URL: https://cyberleninka.ru/article/n/rossiyskiy-indeks-blagopoluchiya-starshego-pokoleniyametodologiya-metodika-aprobatsiya (дата обращения 10.09.2021).

13. Целевые показатели реализации Стратегии действий в интересах граждан старшего поколения в Российской Федерации до 2025 года: приложение к Стратегии действий в интересах граждан старшего поколения в Российской Федерации до 2025 года, утвержденной распоряжением Правительства Российской Федерации от 5 февраля 2016 г. № 164-p. URL: http://static.government.ru/media/files/ 7PvwlIE5X5KwzFPuYtNAZf3aBz61bY5i.pdf (дата обращения 10.09.2021).

14. Будущее российской экономики / М. Алексеев, А.А. Аузан, М.В. Буев и др. - М.: ЭКСМО, 2020. - 240 c.

15. Kuchmaeva O.V. Social activity of elderly Russians and prospects of implementation of the «active ageing» policy // Population and Economics. - 2018. - V. 2. - № 4. - P. 47-84. DOI 10.3897/popecon.2.e36060

16. Григорьева И.А., Уханова Ю.В., Смолева Е.О. Трансформация социальной политики в России в контексте старения населения // Экономические и социальные перемены: факты, тенденции, прогноз. 2019. - T. 12. - № 5. - C. 124-140.

17. Программа «Старшее поколение» благотворительного фонда Елены и Геннадия Тимченко URL: https://timchenkofoundation.org/programmy/starshee-pokolenie (дата обращения 13.09.2021).

18. Электронный сетевой ресурс «Губернаторы.Ru». URL: https://governors.ru (дата обращения 14.09.2021).

19. Томская область в цифрах. Электронная версия публикаций о социально-экономическом положении Томской области // Официальный сайт Территориального органа Федеральной службы государственной статистики по Томской области. URL: https://tmsk.gks.ru/folder/37342 (дата обращения 13.09.2021).

20. Gilleard C., Higgs P. Cultures of ageing: self, citizen and the body. 1st ed. - Routledge, 2000. URL: https://doi.org/10.4324/9781315839530 (дата обращения 12.09.2021).

21. Дмитриева А.В. Социальное включение пожилых: продление занятости или «продвинутый» досуг? // Журнал исследований социальной политики. - 2018. - Т. 16. - № 1. - С. 37-50.

22. Бутуева 3.А. Добровольческая деятельность старших граждан: особенности и мотивы участия // Вестник Института социологии. URL: https:/cyberleninka.ru/article/n/dobrovolcheskaya-deyatelnost-starshihgrazhdan-osobennosti-i-motivy-uchastiya (дата обращения 27.07.2021).

23. Оберемко О. А. Волонтер или доброволец: элементарные объяснения для самоопределения // Социологические исследования. - 2016. - №. 6. - С. 94-101.

24. Ростовская Т.К., Сизикова В.В., Толмачев Д.П. Волонтерская деятельность старшего поколения: региональный аспект // Вестник Южно-Российского государственного технического университета (НПИ). Серия: Социально-экономические науки. - 2021. - Т. 14. - № 3. - С. 61-68.

25. Павлова И.А., Недоспасова О.П. Институциональные функции в анализе ресурсного потенциала старшего поколения // Региональная экономика: теория и практика. - 2021. - Т. 19. - № 5 (488). C. $972-1002$.

Поступила 21.04.2021 2. 
UDC 316.346.32-053.9(571.16)

\title{
ASSESSMENT AND MONITORING OF WELL-BEING OF THE OLD GENERATION IN TOMSK REGION (ON THE MATERIALS OF THE RUSSIAN ELDERLY WELL-BEING INDEX)
}

\author{
Irina A. Pavlova ${ }^{1,2,3}$, \\ iapav@mail.ru \\ Olga P. Nedospasova ${ }^{2}$, \\ olgaeconomy@mail.ru \\ Ilya V. Gumennikov ${ }^{1}$, \\ gumennikov@tpu.ru \\ ${ }^{1}$ National Research Tomsk Polytechnic University, \\ 30, Lenin avenue, Tomsk, 634050, Russia \\ 2 National Research Tomsk State University, \\ 36, Lenin avenue, Tomsk, 634050, Russia \\ ${ }^{3}$ Tomsk State University of Control Systems and Radioelectronics, \\ 40, Lenin avenue, Tomsk, 634050, Russia
}

Irina A. Pavlova, Cand. Sc., associate professor, National Research Tomsk Polytechnic University; associate professor, National Research Tomsk State University; associate professor, Tomsk State University of Control Systems and Radioelectronics.

Olga P. Nedospasova, Dr. Sc., professor, National Research Tomsk State University.

Ilya V. Gumennikov, programmer, National Research Tomsk Polytechnic University.

Relevance. Global demographic aging has actualized the need to find effective solutions to a wide range of problems related to the well-being of older citizens: from financial and economic to emotional and psychological. Focusing public attention on the problems of older people entailed the demand for institutional changes, the adoption of important social and political decisions to improve the quality of life of older citizens as the fastest growing social group, the improvement of traditional and the emergence of new tools for assessing and monitoring progress in this area both at individual level and at the level of regions, countries, international organizations. In addition to indices well known in international practice (Active Aging Index and Global AgeWatch), the Russian research arsenal includes the Russian Elderly Well-being Index (REWI), developed by researchers at the International Scientific and Educational Laboratory of Technologies for Improving the WellBeing of the Elderly at Tomsk Polytechnic University. REWI is objectively not free from the shortcomings inherent in the method as a whole, however, it can be used to track the dynamics of changes in the quality of life of the older generation both for Russia as a whole and for its individual regions, compare their ranking positions within one or several periods, put forward hypotheses about the causes of changes, analyze them, formulate proposals on measures that can improve the quality of life of older people in a particular region. Objective of the study is to analyze the changes in the assessment of the well-being of older people in the Tomsk region based on the REWI materials for 2014, 2016 and 2018 and formulate conclusions based on the results of three rounds of the all-Russian study in the context of the dynamics of the quality of life of older people. Methods: statistical analysis according to the original method for calculating the REWI based on microdata from the Federal State Statistics Service (Rosstat) survey «Comprehensive observation of living conditions of the population» for 2014, 2014 and 2018. Results. The analysis showed (1) the deterioration of values for almost all domains of REWI (economy, society, health, infrastructure and quality of life in the regional dimension) in the whole of the Russian Federation for the entire observation period; (2) the deterioration of the rating positions of the Tomsk region according to the REWI in 2016 and 2018 relative to 2014, (3) a noticeable decrease in the scores for most domains and private index indicators for the Tomsk region in 2018. Conclusions. Based on the results of the analysis of the REWI values for three observation periods, conclusions were formulated both 
about the possibilities and objective limitations in using this index to assess the quality of life and well-being of the older generation in the Russian Federation, and to analyze the dynamics of the corresponding processes in individual regions. Assumptions are put forward about the possible reasons for the negative dynamics of the Tomsk region in the REWI rating both in general and in its individual domains and indicators. Based on the data obtained, preliminary conclusions were drawn about the risks of non-implementation of the national action plan to improve the quality of life of older people and the incomplete coordination of actions carried out in our country with international programs in this area. Perhaps these problems will be able to attract more attention, efforts and resources for their solution against the background of the immediate prospects for the introduction of the Russian elderly well-being index which is built in accordance with the international methodology.

Key words: Elderly, old persons, older generation, well-being, quality of life, composite indicators, Russia, Tomsk Oblast.

\section{REFERENCES}

1. natsionalnykh tselyah razvitiya Rossiyskoy Federatsii na period do 2030 goda [On the national development goals of the Russian Federation for the period up to 2030]. Ukaz Prezidenta Rossiyskoy Federatsii [Decree of the President of the Russian Federation]. Available at: http://www.kremlin.ru/events/president/news/63728 (accessed 25 July 2021).

2. Pavlova I.A., Nedospasova O.P. Institutsionalnye funktsii $\mathrm{v}$ analize resursnogo potentsiala starshego pokoleniya [Institutional functions in the analysis of the resource potential of older generation]. Regionalnaya ekonomika: teoriya i praktika, 2021, vol. 19, no. 5 (488), pp. 972-1002.

3. Active Ageing Index. Available at: https://unece.org/population/active-ageing-index (accessed 25 July 2021).

4. Active Ageing Index Analytical Report (2019). Available at: https://unece.org/info/Population/pub/2804 (accessed 26 July 2021).

5. Global Age Watch Insights Report (2018). Available at: https://www.helpage.org/resources/publications/ $?$ ssearch $=$ Global + AgeWatch $+\& a d v=0 \&$ topic $=0 \&$ region=0\&language=0\&type $=0($ accessed 27 July 2021).

6. 2002 Madrid International Plan of Action on Aging. Available at: https://www.un.org/ru/documents/decl_conv/declarations/ageing_program.shtml (accessed 28 July 2021).

7. Strategiya deystviy v interesakh grazhdan starshego pokoleniya v Rossiyskoy Federatsii do 2025 goda [Strategy of actions in the interests of citizens of the older generation in the Russian Federation until 2025]. Ofitsialny sayt Ministerstva truda $i$ sotsialnogo razvitiya $R F$. Available at: https://mintrud.gov.ru/ministry/programms/37/2 (accessed 17 September 2021).

8. Natsionlny proekt «Demografiya» [National project «Demography»]. Ofitsialny sayt Ministerstva truda $i$ sotsialnogo razvitiya $R F$. Available at: https://xn-80aapampemcchfmo7a3c9ehj.xn--p1ai/projects/demografiya (accessed 6 September 2021).

9. Federalny proekt «Starshee pokoleni» [Federal project «Older generation»]. Ofitsialny sayt Ministerstva truda $i$ sotsialnogo razvitiya $R F$. Available at: https://mintrud.gov.ru/ministry/programms/demography/3. (accessed 28 July 2021).

10. Ovcharova L.N., Morozova M.A., Sidorenko A.V. Kontseptsiya politiki aktivnogo dolgoletiya: nauchnometodologicheskiy doklad [The concept of the policy of active aging: scientific and methodological report]. K XXI Aprelskoy mezhdunarodnoy nauchnoy konferentsii po problemam razvitiya ekonomiki $i$ obshshestva [XXI April International Scientific Conference on the Development of Economy and Society]. Eds. L.N. Ovcharova, M.A. Morozova, O.V. Sinyavskaya. Moscow, Vysshaya shkola ekonomiki Publ. house, 2020. 40 p.

11. Ob utverzhdenii metodiki rascheta Indeksa aktivnogo dolgoletiya $v$ Rossiyskoy Federatsii [On approval of the methodology for calculating the Index of active aging in the Russian Federation]. Prikaz Federalnoy sluzhby gosudarstvennoy statistiki Ministerstva ekonomicheskogo razvitiya RF ot 31 oktyabrya 2019 g. no. 634 [Order of Rosstat from 31 October, 2019 no. 634: order of the Federal State Statistics Service of the Ministry of Economic Development of the Russian Federation]. Available at: https://docs.cntd.ru/document/563664925 (accessed 8 October 2021).

12. Pavlova I.A., Monastyrny E.A., Gumennikov I.V., Barysheva G.A. Rossiyskiy indeks blagopoluchiya starshego pokoleniya: metodologiya, metodika, aprobatsiya [Russian elderly well-being index: methodology, technique, testing]. The Journal of Social Policy Studies. Available at: https://cyberleninka.ru/article/n/rossiyskiy-indeks-blagopoluchiya-starshego-pokoleniya-metodologiya-metodika-aprobatsiya (accessed 10 September 2021). 
13. Tselevye pokazateli realizatsii Strategii deistviy $v$ interesakh grazhdan starshego pokoleniya $v$ Rossiyskoy Federatsii do 2025 goda [Target indicators for the implementation of the Strategy of Action in the Interests of Older Citizens in the Russian Federation until 2025]. Prilozhenie k Strategii deystviy v interesakh grazhdan starshego pokoleniya v Rossiyskoy Federatsii do 2025 goda, utverzhdennoy rasporyazheniem Pravitel'stva Rossiyskoy Federatsii of 5 fevralya 2016 g. № 164-r [Appendix to the Strategy of Action in the Interests of Citizens of the Older Generation in the Russian Federation until 2025, approved by the order of the Government of the Russian Federation dated February 5, 2016 No. 164-r]. Available at: http://static.government.ru/media/files/7PvwlIE5X5KwzFPuYtNAZf3aBz61bY5i.pdf (accessed 10 September 2021).

14. Alekseev M., Auzan A.A., Buev M.V. Budushchee rossiyskoy ekonomiki [Future of Russian economics]. Moscow, EKSMO Publ., 2020. 240 p.

15. Kuchmaeva O. Social activity of elderly Russians and prospects of implementation of the «active ageing» policy. Population and Economics, 2018, vol. 2, no. 4, pp. 47-84. DOI 10.3897/popecon.2.e36060.

16. Grigoreva I.A., Ukhanova Yu.V., Smoleva E.O. Transformatsiya sotsialnoy politiki v Rossii v kontekste stareniya naseleniya [Transformation of social policy in Russia in the context of population aging]. Ekonomicheskie $i$ sotsialnye peremeny: fakty, tendentsii, prognoz, 2019, vol. 12, no. 5, pp.124-140.

17. Programma «Starshee pokolenie» blagotvoritelnogo fonda Eleny i Gennadiya Timchenko [The «Older Generation» program of the Elena and Gennady Timchenko Charitable Foundation]. Ofitsialny sayt blagotvoritelnogo fonda Eleny $i$ Gennadiya Timchenko [Official site of the Elena and Gennady Timchenko charitable foundation]. Available at: https://timchenkofoundation.org/programmy/starshee-pokolenie (accessed 13 September 2021).

18. Elektronny setevoy resurs «Gubernatory.Ru» [Official site «Governors.Ru»]. Available at: https://governors.ru (accessed 14 September 2021).

19. Tomskaya oblast $v$ tsifrakh. Elektronnaya versiya publikatsiy o sotsialno-ekonomicheskom polozhenii Tomskoy oblasti [Tomsk Oblast in figures. Electronic version of publications on the socio-economic situation of the Tomsk region]. Ofitsialny sayt Territorialnogo organa Federalnoy sluzhby gosudarstvennoy statistiki po Tomskoy oblasti [Official website of the Territorial Body of the Federal State Statistics Service for Tomsk Region]. Available at: https://tmsk.gks.ru/folder/37342 (accessed 13 September 2021).

20. Gilleard C., Higgs P. Cultures of Ageing: Self, Citizen and the Body. $1^{\text {st }}$ ed. Routledge, 2000. Available at: https://doi.org/10.4324/9781315839530 (accessed: 12 September 2021).

21. Dmitrieva A.V. Sotsialnoe vklyuchenie pozhilykh: prodlenie zanyatosti ili «prodvinuty» dosug? [Social inclusion of the elderly: prolongation of employment or «advanced» leisure?]. Zhurnal issledovaniy sotsialnoy politiki, 2018, vol. 16, no. 1, pp. 37-50.

22. Butueva Z. Dobrovolcheskaya deyatelnost starshikh grazhdan: osobennosti i motivy uchastiya [Volunteer activity of senior citizens: features and motives of participation]. Vestnik Instituta sotsiologii. Available at: https://cyberleninka.ru/article/n/dobrovolcheskaya-deyatelnost-starshih-grazhdan-osobennosti-i-motivyuchastiya (accessed 27 July 2021).

23. Oberemko O.A. Volonter ili dobrovolets: elementarnye obyasneniya dlya samoopredeleniya [Volunteer or dobrovolets: basic explanations for self-determination]. Sotsiologicheskie issledovaniya, 2016, no. 6, pp. 94-101.

24. Rostovskaya T.K., Sizikova V.V., Tolmachev D.P. Volonterskaya deyatelnost starshego pokolenia: regionalny aspekt [Volunteer activity of the older generation: a regional aspect]. Bulletin of the South-Russian state technical University (NPI) Series Socio-economic Sciences, 2021, vol. 14, no. 3, pp. 61-68.

25. Pavlova I.A., Nedospasova O.P. Institutsionalnye funktsii $\mathrm{v}$ analize resursnogo potentsiala starshego pokoleniya [Institutional functions in the analysis of the resource potential of the older generation]. Regionalnaya ekonomika: teoriya i praktika, 2021, vol. 19, no. 5 (488), pp. 972-1002.

Received: 21 April 2021. 